\title{
AVALIAÇÃO ECONOMICA DA PRODUÇÃO DE ROSA DE CORTE (Rosa sp), EM CAMPO E EM ESTUFA, SOB CONDIÇÕES DE RISCO, NO MUNICÍPIO DE HOLAMBRA- SP: ESTUDO DE CASOS
}

\section{ETIÉNNE GROOT}

Engenheiro Agrônomo

Orientador: Prof. Dr. EVARISTO MARZABAL NEVES

Dissertação apresentada à Escola Superior de Agricultura "Luiz de Queiroz", Universidade de São Paulo, para a obtenção do título de Mestre em Ciências, Área de Concentração: Economia Aplicada.

P I R A C I C A B A

Estado de São Paulo - Brasil

Setembro - 2003 


\section{ERRATA}

Autor: ETIÉNNE GROOT - Avaliação economica da produção de rosa de corte (rosa sp.), em campo e em estufa, sob condição de risco, no município de holambra - sp: estudo de casos

\begin{tabular}{|c|c|c|c|c|}
\hline p. & ítem & Linha & onde se lê & leia-se \\
\hline ix & Lista de tabelas & Décima quarta & $\begin{array}{l}\ldots \text { entre o período } 12 \text { (zero) e } \\
23 \text {, no ... }\end{array}$ & $\begin{array}{l}\ldots \text { entre o período } 12 \text { e } 23 \text {, } \\
\text { no ... }\end{array}$ \\
\hline $\mathrm{XV}$ & Resumo & Sexta & $\begin{array}{l}\ldots \text { da rosa é de } \mathrm{R} \$ \\
2,26 / \text { dúzia... }\end{array}$ & $\begin{array}{l}\ldots \text { da rosa são de } \mathrm{R} \$ \\
2,26 / \text { dúzia... }\end{array}$ \\
\hline$x v i$ & Summary & terceira & ...in green house production... & $\begin{array}{l}\ldots \quad \text { in } \\
\text { production... }\end{array}$ \\
\hline xvi & Summary & Sexta & ... sold per area & ... sold per area. \\
\hline xvi & Summary & décima & $\ldots$ as : net values, $\ldots$ & $\ldots$ as: net values,.. \\
\hline $\mathrm{xvi}$ & Summary & décima & ... rate of return & ... rate of return, \\
\hline xvi & Summary & $\begin{array}{l}\text { Décima } \\
\text { segunda }\end{array}$ & ... (Monte Carlo) The results... & $\begin{array}{l}\ldots \text { (Monte Carlo). The } \\
\text { results... }\end{array}$ \\
\hline $\mathrm{xvi}$ & Summary & $\begin{array}{l}\text { Décima } \\
\text { segunda }\end{array}$ & $\ldots$ that green house rose $\ldots$ & $\ldots$ that greenhouse rose ... \\
\hline xvi & Summary & Décima & $\begin{array}{l}\ldots \quad \mathrm{R} \$ \quad 1,63 / \text { dozen } \\
\text { respectively).... }\end{array}$ & $\begin{array}{l}\ldots \quad \mathrm{R} \$ \quad 1,63 / \text { dozen, } \\
\text { respectively).... }\end{array}$ \\
\hline xvi & Summary & Décima & ... The present net values... & ... The net present values... \\
\hline$x \vee 1$ & Sum & Décim & $\begin{array}{l}\ldots \text { in the green house } \\
\text { production.... }\end{array}$ & $\begin{array}{l}\ldots \text { in the greenhouse } \\
\text { production... }\end{array}$ \\
\hline xvi & Summary & Décima & production.. As . & ... field production. As ... \\
\hline $\mathrm{xV} 1$ & $\mathrm{y}$ & Décin & $\ldots g$ & $\begin{array}{l}\ldots \text { greenhouse prod } \\
\ldots\end{array}$ \\
\hline$x v i$ & Summary & Décim & $\ldots$ by the present total... & $\begin{array}{l}\ldots \text { by the net present total } \\
\ldots\end{array}$ \\
\hline xvil & $\mathrm{Su}$ & 1 & $\ldots$ in & $\ldots$ in greenh \\
\hline XVi1 & $\mathrm{y}$ & Quá & th ... & ... production. With \\
\hline$x \mathrm{vil}$ & Sur & Qua & $\ldots(1$ & ... (indice) shows... \\
\hline V11 & Sum & Quinta & risk... & $\ldots$ of return, under risk ... \\
\hline xvii & Sum & étima & iction ... & $\begin{array}{l}\ldots \text { greenhouse productic } \\
\ldots\end{array}$ \\
\hline xvii & Sun & Oit & By & Under the assumptions,... \\
\hline$X \vee 1$ & Sur & Nona & llyses study, ... & $\begin{array}{l}\ldots \text { economic analys } \\
\text { study, } \ldots\end{array}$ \\
\hline$x \vee i$ & & & $\ldots 0$ & ... of a greenhouse. \\
\hline$x$ vii & Sum & Décima & vould be & $\begin{array}{l}\ldots \text { field one, the latter } \\
\text { would be ... }\end{array}$ \\
\hline $\mathrm{xV} 1$ & Summary & $\begin{array}{l}\text { Décima } \\
\text { primeira }\end{array}$ & ... more attractive The ... & ... more attractive. The ... \\
\hline xvii & Summary & Décima & $\ldots$ income a re $:$ prices, trade & $\begin{array}{l}\ldots \text { income are: prices, trade } \\
\ldots\end{array}$ \\
\hline $\begin{array}{c}\text { XVil } \\
1\end{array}$ & Summary & Décima sexta & ... hailstones, storms ... & ... hailstones, storms ... \\
\hline 1 & 1 & Décima quarta & $\begin{array}{l}\text {... devido sua ... } \\
\ldots \text { US } \$ 4,0 \text { em média }\end{array}$ & da sua... \\
\hline
\end{tabular}




\title{
Dados Internacionais de Catalogação na Publicação (CIP) DIVISÃO DE BIBLIOTECA E DOCUMENTAÇÃO - ESALQ/USP
}

\author{
Groot, Etiénne \\ Avaliação econômica da produção de rosa de corte (Rosa sp), em campo e em \\ estufa, sob condiçōes de risco, no municipio de Holambra - SP: estudo de casos / \\ Etiénne Groot. - - Piracicaba, 2003. \\ $78 \mathrm{p}$. \\ Dissertação (mestrado) - Escola Superior de Agricultura Luiz de Queiroz, \\ 2003. \\ Bibliografia.
}

1. Análise de risco 2. Custo económico 3. Indicadores económicos 4. Método de Monte Carlo 5. Modelos matemáticos 6. Pós-colheita 7. Rosa I. Título

CDD 338.1759 
Em memória ao meu pai Leonardus Groot 


\section{AGRADECIMENTOS}

À minha querida esposa (Olga) que me deu muita força, incentivou e tem compartilhado as mais adversas situações. Espero, um dia, se possível, retribuir tudo que recebi neste período de nossa convivência matrimonial. Muchas gracias, "Maite Zaitut".

À minha mãe Hermina M. B. G. Weijenborg Groot pelo carinho de estar ao lado de seus filhos nos momentos em que mais a necessitam, e aos demais familiares.

Ao professor Evaristo Marzabal Neves, pelo empenho na orientação do presente trabalho. É um privilégio poder ser orientado por um pesquisador entusiasta e um educador compreensivo e motivador.

Aos professores José Vicente Caixeta-Filho, Roberval de Cássia Ribeiro, Ana Maria P. Lima e Ricardo Shirota que participaram das bancas de avaliação do presente trabalho. Suas sugestões além de enriquecerem o presente trabalho contribuíram, também, à melhoria da minha formação profissional.

Aos produtores André Boersen e Adriano Van Roije, que muy gentilmente contribuíram com dados e principalmente com seus conhecimentos adquiridos por anos sobre a cultura da rosa. Não é possível esquecer pessoas como Godoy, Antonio e tantos outros que convivem diariamente com a produção de rosas e que passaram lições de conhecimento. 
Ao Veiling Holambra, especialmente à Rachel Ferreira e Paulo Van de Broek que apoiaram a pesquisa com o fornecimento de dados, informações e sugestões de nomes de produtores que puderam participar do mesmo.

Ao Departamento de Economia, Administração e Sociologia da ESALQ, pela oportunidade de aumentar os conhecimentos teóricos de economia. À Maielli, pela sua dedicação profissional e pessoal aos alunos da pós-graduação.

Às pessoas que acreditaram que um dia o projeto do mestrado se concretizaria.

Por fim, aos meus amigos e colegas da pós-graduação. Acredito que logo estaremos recordando com muitas saudades do período que passamos juntos. 


\section{SUMÁRIO}

Página

LISTA DE FIGURAS .................................................................. vii

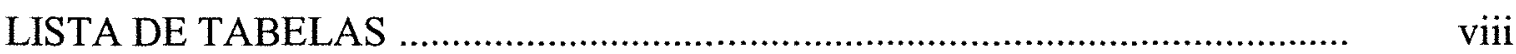

RESUMO .......................................................................................

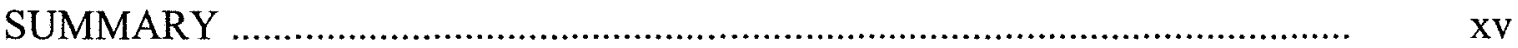

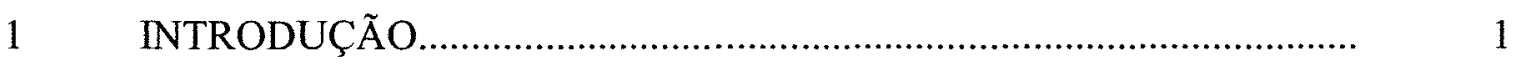

1.1 Estrutura do trabalho............................................................... 8

2 CONSIDERAÇÕES SOBRE OS SISTEMAS DE PRODUÇÃO DE

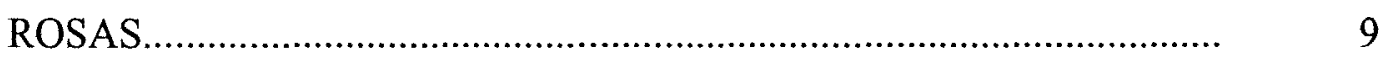

2.1 Vantagens e desvantagens do uso de estufa e algumas tendências........... 9

2.2 Custo de produção da roseira.......................................................... 11

2.3 Principais entrepostos de comercialização de flores e plantas ornamentais em São Paulo................................................................ 13

2.4 Mercado de rosa nos principais entrepostos de São Paulo...................... 15

3 MATERIAL E MÉTODOS.............................................................. 17

Fonte de dados........................................................................ 17

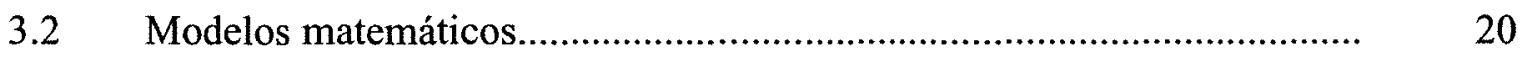

3.2.1 Análise determinista................................................................. 20

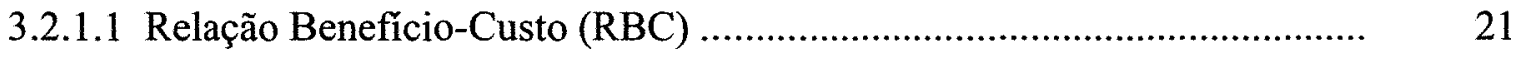

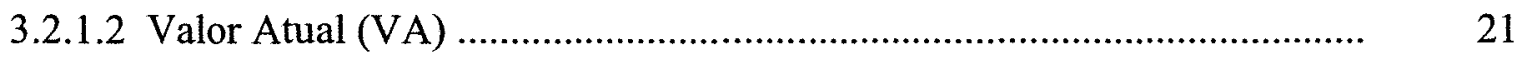

3.2.1.3 "Payback" Simples (PBS) e "Payback" Econômico (PBE)....................... 23

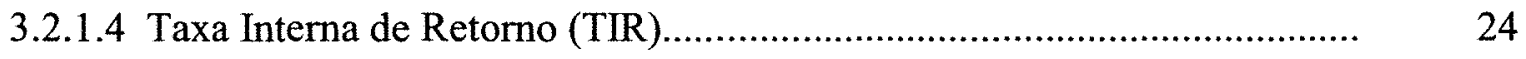

3.2.1.5 Custo Total Atualizado (CTA) .................................................. 25 
3.2.1.6 Custo unitário atualizado (CUA) ......................................................... 26

3.2.2 Análise de risco.................................................................................. 26

3.2.2.1 Processo de simulação e tomada de decisão em condição de risco............. 27

3.2.2.2 Programa ALEAXPRJ.................................................................... 29

3.2.3 Pressuposições e limitações do trabalho ………………………………..... 30

3.2.4 Definições e considerações sobre as variáveis no fluxo de caixa .............. 33

4 RESULTADOS E DISCUSSÃO _....................................................... 39

4.1 Análise determinista .................................................................... 39

4.2 Análise de Risco........................................................................ 50

$5 \quad$ CONCLUSÕES....................................................................... 55

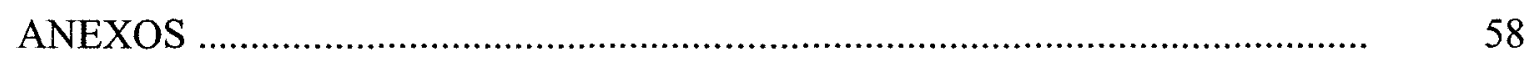

REFERÊNCIAS BIBLIOGRÁFICAS …...................................................... 


\section{LISTA DE FIGURAS}

Página

1 Exportações e importações brasileiras de plantas vivas e produtos de floricultura, entre os anos de 1992 a 2002 .............................................

2 Distribuição de probabilidade da taxa interna de retorno (TIR), para a produção de rosas, da variedade Vegas, nos sistema de campo e estufa, Município de Holambra. Onde $\mathrm{P}(\mathrm{I})$ é a probabilidade de ocorrência do indicador 


\section{LISTA DE TABELAS}

Página

1. Descrição do setor produtivo da Cadeia de Flores e Plantas Ornamentais no Brasil.

2 Produção de flores e plantas ornamentais no Estado de São Paulo, em 1996

3 Fluxo de caixa trimestral, entre os periodos 0 e 7 , para a produção de rosas de corte no sistema de produção em estufa, no Município de Holambra - SP

4 Fluxo de caixa trimestral, entre os períodos 8 e 15, para a produção de rosas de corte no sistema de produção em estufa, no Município de Holambra - SP.

5 Fluxo de caixa para a produção de rosas de corte no sistema de produção a campo, entre o período 0 (zero) e 11 , no Município deHolambra - SP....

6 Fluxo de caixa para a produção de rosas de corte no sistema de produção a campo, entre o período 12 (zero) e 23, no Município de Holambra - SP.

7 Análise determinista do sistema de produção de rosas em campo, da variedade Vegas, no Município de Holambra.

8 Análise determinista do sistema de produção de rosas em estufa, da variedade Vegas, no Município de Holambra.

9 Análise determinista do sistema de produção de rosas em estufa, considerando o custo em função da produção do caso do sistema de produção em campo, da variedade Vegas, no Município de Holambra......

10 Variação percentual dos indicadores à variação do custo de oportunidade do capital. 
11 Análise de sensibilidade, para a produção de rosas em estufa, no Município de Holambra - SP.

12 Análise de sensibilidade, para a produção de rosas em campo aberto, no Município de Holambra - SP.

13 Resultados das simulações do programa ALEAXPRJ, para o sistema de produção de rosas em campo, da variedade Vegas, no Município de Holambra.

14 Resultados das simulações do programa ALEAXPRJ, para o sistema de produção de rosas em estufa, da variedade Vegas, no Município de Holambra.

15 Resultados das simulações do programa ALEAXPRJ, para o sistema de produção de rosas em estufa, com o custo em função da produção do sistema de campo aberto, da variedade Vegas, no Município de Holambra

16 Relação entre os coeficientes de variação dos índices dos econômicos das alternativas de produção de rosas em campo aberto, em estufa e em estufa com os custos em função da produção do sistema de campo............

17 Médias e desvios-padrão das quantidades mensais vendidas por hectare e os respectivos preços médios e seus desvios-padrão por dúzia comercializada (Veiling Holambra), de acordo com o sistema de produção adotado

18 Preços trimestrais mínimos, médios e máximos, de rosas de corte da variedade Vegas, comercializada no Veiling-Holambra.

19 Produções mínimas, mais prováveis e máximas, para 1 ciclo de produção da rosa de corte da variedade Vegas, nos sistema de estufa, no Município de Holambra-SP.

20 Produções mínimas, mais prováveis e máximas para um ciclo de produção da rosa de corte da variedade Vegas, no sistema de campo aberto, no Município de Holambra-SP. 
21 Gastos com materiais para a construção de um hectare de estufa de estrutura de madeira (eucalipto) visando a produção de rosas de corte.......

22 Custo para a construção de um hectare de estufa de estrutura de madeira, para o plantio de rosas de corte no Município de Holambra-SP.

23 Custos por hectare para a implantação de sistema de pulverização, no sistema de estufa.

24 Custos de implantação de sistema de irrigação em um hectare de estufa de rosa.

25 Investimento em estrutura de colheita, para um hectare de rosas de corte, em estufa.

26 Investimento em estrutura de pós-colheita para um hectare de produção de rosas de corte.

27 Investimento em transformador de energia, necessários para conduzir um hectare de lavoura de rosas de corte.

28 Total de investimento em estrutura fixa para produzir rosas de corte em um hectare, no sistema de estufa.

29 Gastos necessários para a troca de plásticos em 1 (um) hectare de estufa de estrutura de madeira.

30 Custo semestral por hectare da remuneração da terra, no município de Holambra-SP.

31 Custos semestrais com manutenção para um hectare de produção de rosas de corte, no sistema de estufa, no Município de Holambra-SP.

32 Custos com manutenção e administrativos, num semestre, para um hectare de produção de rosas em estufa.

33 Custo de preparo do solo e implantação de um hectare de rosas de corte, no Município de Holambra-SP.....

34 Custo operacional/semestre, no sistema de produção de rosas de corte em estufa, no Município de Holambra-SP. 
35 Custos variáveis em função da produção do roseiral, para o sistema de produção de rosas de corte em estufa no Município de Holambra-SP........

36 Custos e investimentos totais para a produção em um hectare de rosas de corte, da variedade Vegas, no Município de Holambra

37 Prejuízos trimestrais mínimos, mais prováveis e máximos de rosas enviadas ao centro de comercialização (Veiling) e que não foram vendidas, para o sistema de estufa.

38 Sistema de irrigação por aspersão, utilizado na produção de um hectare de rosa de campo.

39 Custo de implantação de sistema fixo de pulverização em um hectare de produção de rosas em campo.

40 Investimento demandado, em um hectare, para o sistema fixo de colheita da rosa produzida no campo.

41 Investimentos necessários em estrutura fixa de pós-colheita para um hectare de rosa produzida no sistema de campo.

42 Investimento em transformador de energia, necessários para conduzir um hectare de lavoura de rosas de corte.

43 Total de investimentos em estrutura fixa necessário para produzir em um hectare de rosas de campo.

44 Custo semestral por hectare da remuneração da terra, no município de Holambra - SP.

45 Custos semestrais com manutenção para um hectare de produção de rosas de corte, no sistema de campo, no Município de Holambra-SP.

46 Custos com manutenção e administrativos, num semestre, para um hectare de produção de rosas em campo.

47 Gastos, de um hectare, para o preparo do solo e implantação da cultura, no sistema de produção de rosas de corte produzidas em campo.

48 Custos operacionais para um hectare da cultura da rosa de corte, no sistema de campo aberto. 
49 Custo em função da produção de um carrinho tipo Veiling (225 dúzias), para o sistema de produção de rosas a campo.

50 Custos e investimentos totais para a produção em um hectare de rosas de corte, da variedade Vegas, no Município de Holambra..............................

51 Prejuízos trimestrais mínimos, mais prováveis e máximos de rosas enviadas ao centro de comercialização (Veiling) e que não foram vendidas, para o sistema de campo aberto. 


\section{AVALIAÇÃO ECONOMICA DA PRODUÇÃo DE ROSA DE CORTE (Rosa sp), EM CAMPO E EM ESTUFA, SOB CONDIÇÕES DE RISCO, NO MUNICÍPIO DE HOLAMBRA-SP: ESTUDO DE CASOS}

Autor: ETIÉNNE GROOT

Orientador: Prof. Dr. EVARISTO MARZABAL NEVES

\section{RESUMO}

Este trabalho tem por objetivo estabelecer indicadores econômicos, incorporando risco, para duas alternativas de produção, à campo e em estufa, de rosas de corte da variedade Vegas, no município de Holambra - SP. Parte-se da hipótese de que o maior investimento inicial exigido para a produção de rosas em estufa seria compensado, temporalmente, em relação à produção em campo aberto, por produzir hastes de melhor qualidade e com maior uniformidade implicando, assim, em maiores preços e quantidades vendidas por área. Para tanto, a fonte de informação sobre os sistemas de produção são produtores de rosas do Município de Holambra. Os preços considerados se apóiam em dados fornecidos pelo Veiling-Holambra (convertidos em reais de outubro de 2002) e as taxas de juros são de $10,2 \%, 20 \%$ e $30 \%$ ao ano. A obtenção dos indicadores econômicos das análises determinista e de risco deu-se através da utilização do software ALEAXPRJ, que utiliza o método de Monte Carlo. Os resultados da pesquisa mostram que as rosas de estufa apresentam preços de venda superiores que as produzidas a campo, $R \$ 2,71 /$ dúzia e $R \$ 1,63 /$ dúzia, respectivamente. A geração de receita em valores 
atuais (VA), são: $R \$ 133.183,46 /$ ha em quatro anos de produção em estufa e, $R \$$ 53.952,04/ha em seis anos de produção à campo aberto. Como a produção em estufa demanda maior fluxo de capital, com custo total atualizado (CTA) de R\$431.518,34/ha contra R\$168.142,77/ha no sistema de campo, o comparativo para a relação beneficiocusto se mostra favorável à produção de rosas à campo. Os custos unitários atualizados (CUA) da rosa é de $\mathrm{R} \$ 2,26 /$ dúzia (out./2002) quando produzida em estufa e de $\mathrm{R} \$$ 1,31/dúzia no cultivo de campo. Os valores médios obtidos para as taxas internas de retorno (TIR), em condição de risco, para um custo de oportunidade de 10,2\%, são: $54,01 \%$ a. a. para o projeto de produção a campo e $50,17 \%$ a. a. para a produção em estufa e, de acordo com a distribuição de probabilidade deste indice, existe a possibilidade de os dois sistemas de produção de rosas apresentarem a mesma taxa interna de retorno. Nas condições do estudo, o projeto que apresenta melhor atratividade para a produção de rosas de corte da variedade Vegas, no município de Holambra - SP, é o sistema em campo aberto. Porém, a inclusão dos custos de colheita, pós-colheita do sistema de campo para o sistema de estufa, sinaliza para este segundo sistema uma melhor atratividade. Os fatores que mais influenciam na variação de rentabilidade são, em ordem decrescente, os preços, quantidade comercializada (fatores geradores de receita), custo adicional de produção (colheita, pós-colheita e a colocação e ajustamento de redinhas). O fator que menos interfere na rentabilidade é o custo não faturado, ou seja, os produtos levados ao entreposto e que não são comercializados. $O$ estudo remete a outras análises em condições de risco revelando que em futuros estudos são necessários a inserção de outras variedades de rosas e a consideração de outros fatores não controláveis como os efeitos de chuvas de granizo, fortes geadas, além da incorporação de um horizonte temporal de preço e produção mais longos. 
ECONOMIC EVALUATION OF CUT ROSE PRODUCTION (Rosa sp.), FIELD AND GREEN HOUSE SYSTEMS UNDER RISK CONDICTIONS, HOLAMBRA -SP: CASE STUDY

\author{
Author: ETIÉNNE GROOT \\ Adviser: Prof. Dr. EVARISTO MARZABAL NEVES
}

\title{
SUMMARY
}

The purpose of this study is to establish economic outlines for two alternatives of cut rose production (open field and green house) of Vegas variety, in Holambra SP, under risk conditions. The hypothesis was that a larger initial investment in green house production would be compensated, during production period in relation to open field production, by producing better quality stems and consequently roses with better quality and uniformity resulting higher sales prices and quantities sold per area. The information sources were obtained by interviews and questionaries applied to growers and prices collected from Veiling-Holambra (Oct. 2002 base). The opportunity costs (interest rate) are $10,2 \%$ (Selic), $20 \%$ and $30 \%$ as a market approach. In this economic analysis some indicators as :net values, benefit-cost ratio, internal rate of return, payback period and discounted unit cost were analysed using ALEAXPRJ software (Monte Carlo method) The results show that green house rose prices are higher than the field produced ones ( $R \$ 2,71$ a dozen and $R \$ 1,63 /$ dozen , respectively). The present net values are: $\mathrm{R} \$ 113.183,46 /$ hectare in the green house production considering a four year period, and $\mathrm{R} \$ 53.952,04 /$ hectare for a six year period in open field production.. As green house production requires more capital flow, demonstrated by the present total 
cost value of $R \$ 431.518,34 /$ hectare to $R \$ 168.142,77 /$ hectare in field system, the benefit-cost ratio is more attractive to field rose production. The rose costs are $R \$$ 2,26/dozen (Oct. 2002) when produced in green houses and $R \$ 1,31 /$ dozen in open field production. . With the probability distribuition, this outcome (indice), shows that there is no possibility that costs present the same value. The internal rate of return, at risk conditions, are $54,01 \%$ per year for the field production project and 50,17\% per year for green house production and according to the probability distribution, there are chances that both production systems have the same value. By assumptions, established in this economic analyses study, there are indicators that point out that an open field system is more attractive. However, including the harvest and post harvest costs of a green house system in relation to an open field one, it would be economically more attractive The variables which reflected strong influence in the income are : prices, trade quantities, additional costs in harvest operations and flower protection net adjusts. The income is less sensitive to costs generated for roses set to market and not traded (rejected). New studies have to be made incorporating other, uncontrollable, variables such as: frost, hailstones, storms as well as including long term prices and production. 


\section{INTRODUÇÃO}

Face seus impactos alocativos e distributivos, a floricultura vem assumindo papel importante na economia do agronegócio mundial e brasileiro. Estimativas recentes revelam que mundialmente o setor vem movimentando cerca de US\$ 25 bilhões, enquanto que a floricultura brasileira ainda representa uma fatia pequena, com um mercado de apenas $R \$ 2$ bilhões ou US\$ 650 milhões (Zafalon, 2003). Projeções de Kiyuna et al. (2001), citadas por Florabrasilis (2002), apontam que o setor varejista faturou entre $\mathrm{R} \$ 1,36$ a 1,53 bilhões no ano de 1999, sendo que o setor produtivo movimentou ao redor de $\mathrm{R} \$ 322,6$ milhões/ano.

O mercado brasileiro vem evoluindo gradativamente e com tendência a um contínuo crescimento, não só pela atração motivada pelo mercado doméstico devido sua maior popularização, mas, principalmente, pela exportação e atual atenção que o setor vem provocando aos governos (Federal e Estadual) e institutos de pesquisa. Segundo Matsunaga (1997), o mercado brasileiro pode crescer ainda muito devido ao baixo consumo per capita de flores e plantas ornamentais (US\$ 4,0 em média em 1995), que hoje se estima em US\$ 6,0 per capita (Fernandes, citado por Zafalon, 2003). Países como Noruega, Suíça, Dinamarca e Itália chegam a um consumo maior que US\$ 100 por habitante por ano. Outros países, como a Alemanha, Áustria, Holanda, Bélgica, França, Japão e Estados Unidos, projetam um consumo superior a US\$ 40/habitante/ano. Kampf (1997) relata que a expectativa de crescimento do ramo de produção de flores e plantas ornamentais, no Brasil, está na ordem de $20 \%$ ao ano. 
Arruda et al. (1996) lembram que o setor de produção de flores e plantas ornamentais brasileiro visa praticamente o mercado interno, mas com alto potencial para exportação, abertura que é propiciada pela produção de diferentes variedades de flores e atendimento aos gostos e preferências do consumidor externo. As exportações da década de 90 situavam-se entre $1,5 \%$ a 2,0\% (US\$ 10 a 14 milhões) da produção nacional, sendo que as flores mais exportadas têm sido as flores tropicais, gladíolos, rosas, bulbos, mudas de cordelineas e dracenas (Figura 1). Mas, enquanto o Brasil exporta, por ano, entre US\$ 15 a 20 milhões, a Colômbia vem obtendo receitas anuais ao redor de US\$ 600 milhões.

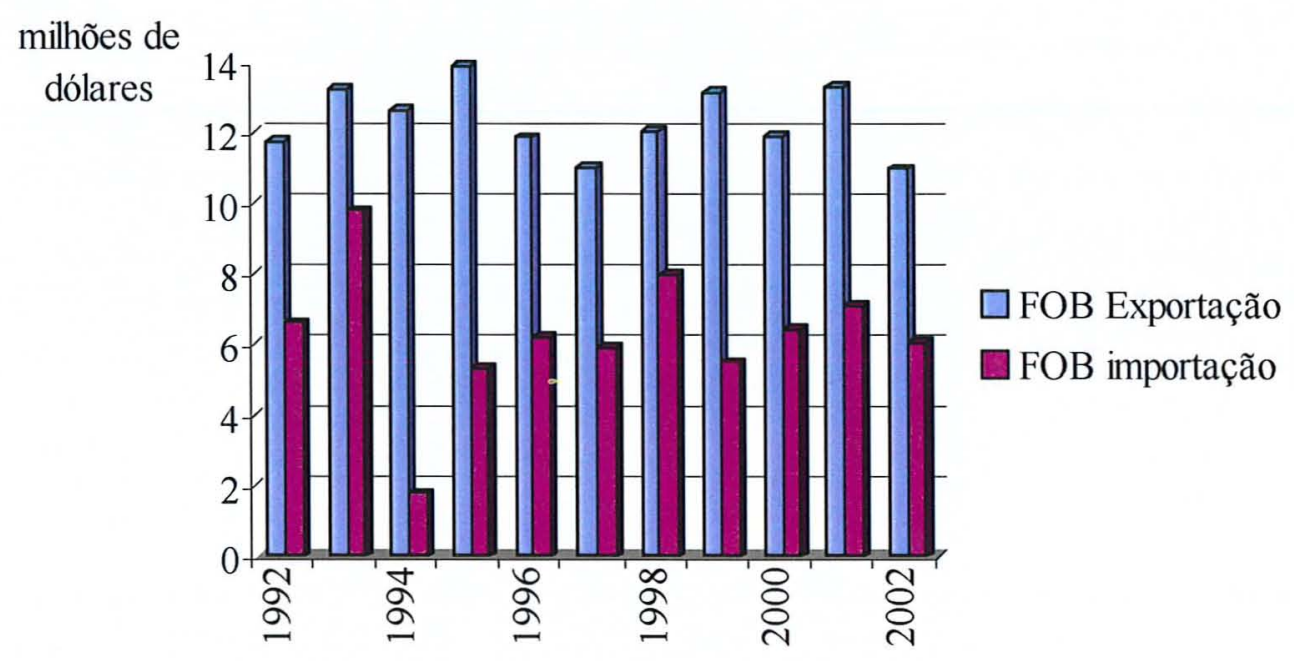

Figura 1 - Exportações e importações brasileiras de plantas vivas e produtos de floricultura, entre os anos de 1992 a 2002.

Fonte: SECEX, citado pela Florabrasilis (2002)

Nota: Os dados de 2002 representam as exportações e importações no período de janeiro à setembro.

Os principais países exportadores de flores e plantas ornamentais na América do Sul são a Colômbia e o Equador. Os fatores que foram decisivos para estes países na conquista de novos mercados foi o acordo fixado entre estes países e os Estados Unidos da América, o chamado "Andean Trade Preference Act", firmado em 1992, e as condições ambientais excepcionais que regulam a oferta do produto e que tornam a sua qualidade extremamente competitiva. Segundo Weisman (2003), mais de 60\% do 
mercado de rosas dos EUA são colombianas, mais atrativas e baratas, já que as rosas dos Estados Unidos são caras devido aos custos gerados pelo alto valor da mão-de-obra.

Por tratar-se de processos de produção intensivos, a importância social quanto à geração de empregos no setor de flores e plantas ornamentais (produção e comercialização) é indiscutivel. Arruda et al. (1996) acreditam que a cadeia de produção de flores e plantas ornamentais gera 28,5 mil postos de trabalho. Já para Florabrasilis (2002) esse número de trabalhadores possa ser algo ao redor de 55 mil. Arruda et al. (1996) destacam que 4\% estão envolvidos no ramo de insumos, $45 \%$ na produção, $7 \%$ na distribuição das flores e plantas e $45 \%$ trabalham no varejo. Kampf (1997) cita que no setor produtivo, no Estado de São Paulo, 10\% é mão-de-obra familiar, $86 \%$ mensalistas e $4 \%$ compostos por diaristas. A pequena proporção de mão-de-obra familiar demonstra o caráter empresarial no Estado.

Ainda, chamam a atenção, em termos alocativos por uso e serviços de fatores de produção, os estudos recentes desenvolvidos pela Embrapa (Empresa Brasileira de Pesquisa Agropecuária) Agroindustrial Tropical. Segundo Terao, citado por Zafalon (2003), enquanto que um hectare plantado com frutas, como a uva e manga, emprega até 3 pessoas e a receita chega a $\mathrm{R} \$ 10$ mil por ano (a valores de 2002), o cultivo de rosa, na mesma área, emprega até 15 pessoas e a receita varia de $R \$ 100$ a $R \$ 200$ mil. Nas contas da Embrapa, o plantio de flores em um hectare pode render 30 vezes mais que o milho e três vezes mais que a uva e a manga. Porém, um alerta, o setor é difícil e exige acurado conhecimento científico e empírico, alta tecnologia no cultivo, qualidade dos produtos e gerenciamento e profissionalização para atender o mercado externo, exigente na continuidade de oferta e suficiência no volume.

Estimativas da Florabrasilis (2002) revelam que existem 2,5 mil produtores de flores e plantas ornamentais no Brasil, após pesquisarem 1.356 propriedades Estas propriedades estendem-se por 5.118,7 hectares, predominando o cultivo em campo aberto. A área média explorada por propriedade é de 3,77 ha, sendo os Estados de Santa 
Catarina seguido por São Paulo, os que apresentam as propriedades com maiores extensões produtivas.

O Estado de São Paulo é que possui maior número de produtores e área plantada: $70 \%$ da área nacional. No entanto, na utilização de estufas é o quarto colocado, ficando após o Espirito Santo, Minas Gerais e Rio Grande do Sul. A utilização de estufas pode ser entendida como uma forma de avaliar a capacidade de absorção de tecnologia e capitalização dos produtores de flores e plantas ornamentais.

Na pesquisa Florabrasilis (2002), foi avaliado ainda o perfil gerencial dos produtores, enumerando os que realizam escrituração, participam de treinamentos, utilizam crédito e os que possuem assistência técnica (Tabela 1). $O$ uso de crédito pode ser influenciado por diversos fatores, especialmente pelo custo do capital (valor da taxa de juros) e pela capacidade de gerenciar o empreendimento que o produtor possui. Com os dados da Tabela 1, é possível verificar que o item que apresenta maior correlação com o uso de crédito é a prática da escrituração (76\%), seguido pelo tamanho da área de produção $(23 \%)$.

Atualmente, as fronteiras de produção de flores e plantas ornamentais estão avançando para outras regiões, em busca de climas mais favoráveis e proporcionando produtos de melhor qualidade a um preço competitivo. O Estado do Ceará está sendo o novo destino de produtores que visam o mercado externo, sobretudo para produzir rosas (a exemplo do Grupo Reijers - empresa brasileira tradicional na produção de rosas). Segundo Correia et al. (2003), este estado possui posição geográfica favorável (mais próximo da Europa e dos EUA, maior luminosidade e menores variações climáticas entre as estações do ano) e, em regiões como a Serra de Ibiapaba, onde a altitude varia entre 750 a 900m, o clima é propício à atividade. Segundo estes autores, as condições climáticas proporcionam aos roseirais desta região uma produtividade de 250 hastes por metro quadrado por ano, enquanto que em São Paulo a mesma é de 120 hastes $/ \mathrm{m}^{2} /$ ano. 


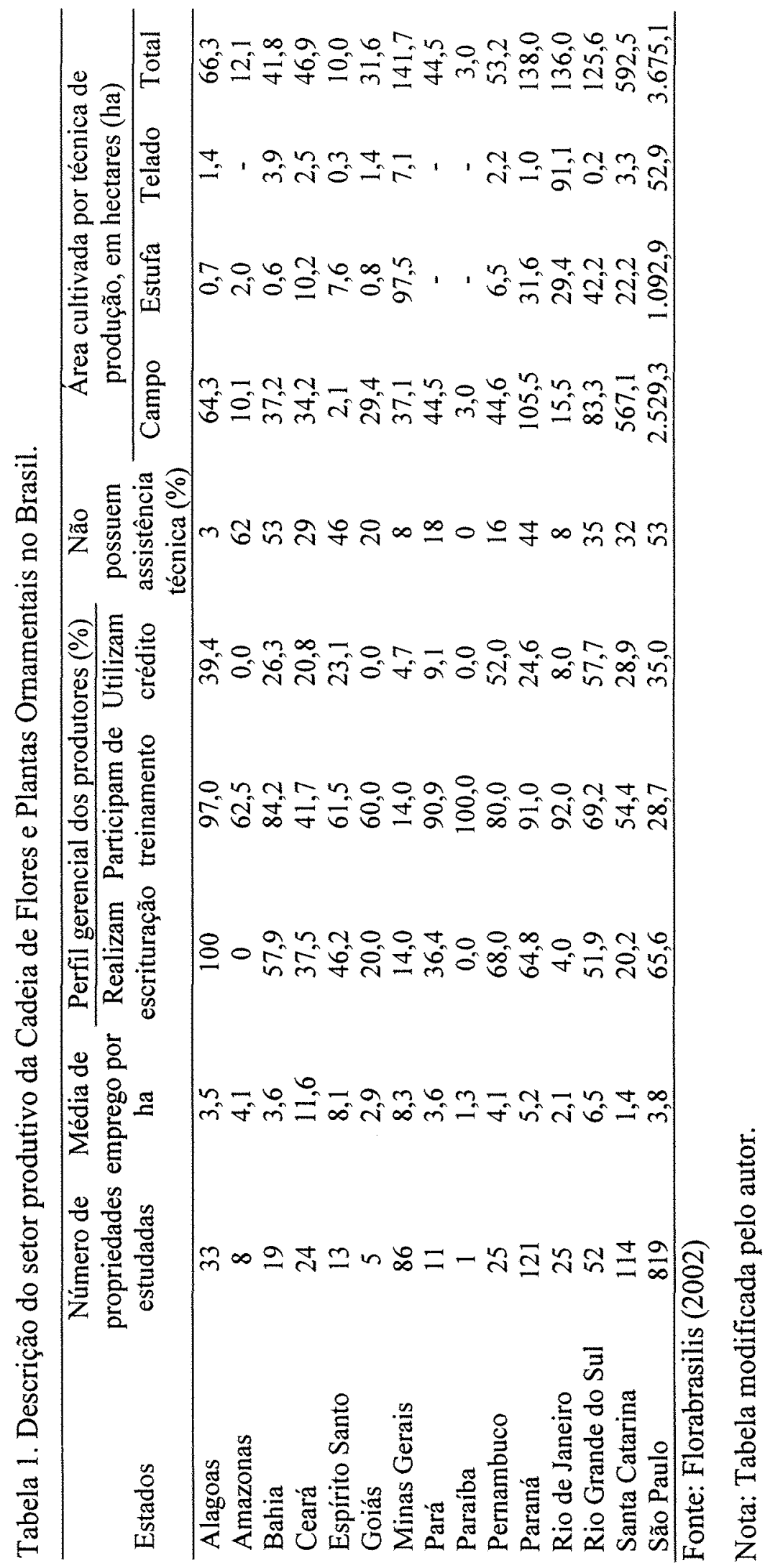


A participação cearense às exportações brasileiras passou de 0,2\% em 1996 para 14,8\% no ano de 2002.

O mercado de flores e plantas ornamentais é dinâmico e está em expansão, passando continuamente por mudanças. A rosa, que é um produto tradicional dentro da cadeia de produção de flores (para Laws, 2001, é considerada "a rainha das flores"), vem perdendo participação no mercado das flores. Segundo Matsunaga et al. (1995), em 1976 eram vendidas no CEAGESP em São Paulo cerca de 30 milhões de dúzias de rosas que, em 1991, caiu para 4,8 milhões de dúzias. Esta redução nas vendas, segundo o mesmo autor, se deu pela concorrência de novas plantas de corte, mudanças nos gostos e preferências dos consumidores diante da diversificação de produção e pelo surgimento de novas regiões produtoras de rosas, aumentando a oferta e provocando queda dos preços.

Em São Paulo, o cultivo de rosa em estufa ainda é relativamente pequeno quando comparado às produções de crisântemo, branquinha, antúrio, mini-rosa, lisianthus (Tabela 2). Porém, é um sistema de produção com indicações de crescimento visando a qualidade, uniformidade e atendimento aos consumidores mais exigentes. De acordo com a Florabrasilis (2002), dos 1.356 produtores pesquisados a cultura que abrange maior área é da rosa com 426 hectares, seguida por 234,5 ha de crisântemo, 101,8 ha de helicônia e 113,7 ha com outras flores de corte.

Estas alternâncias de mercado e a maior oferta de outras flores induziram os produtores de rosas à busca de sistemas alternativos de produção visando a sua manutenção no mercado. Uma forma encontrada para diferenciarem o seu produto e aumentarem a sua competitividade foi a produção de rosas em estufas. De acordo com Sentelhas \& Santos (1995), o cultivo protegido possibilita à entressafra uma regularização da oferta, melhoria da qualidade dos produtos e possibilita a produção de flores em regiões onde o clima é crítico, melhorando/propiciando o desenvolvimento das plantas. 
Tabela 2. Produção de flores e plantas ornamentais no Estado de São Paulo, em 1996.

\begin{tabular}{lrccc}
\hline & & \multicolumn{3}{c}{ Áreas plantadas de acordo com o sistema } \\
\cline { 3 - 5 } Discriminação & Número de pés & Campo aberto (ha) & Telado (ha) & Estufa (ha) \\
\hline Antúrio & $63.000,00$ & 0,00 & 1,22 & 0,19 \\
Boca de Leão & $1.000,00$ & 0,00 & 0,00 & 0,43 \\
Catleyas e afins & $192.000,00$ & 0,00 & 0,57 & 4,15 \\
Crisântemo & $314.000,00$ & 21,98 & 1,10 & 92,75 \\
Dracena & $30.000,00$ & 1,00 & 0,10 & 0,00 \\
Estrelícia & $64.000,00$ & 9,00 & 0,00 & 0,02 \\
Gérbera & $90.000,00$ & 0,00 & 0,00 & 4,26 \\
Mini-rosa & $18.000,00$ & 0,00 & 0,00 & 0,53 \\
Rosa & $3.056 .000,00$ & 146,58 & 0,00 & 9,30 \\
\hline
\end{tabular}

Fonte: Adaptação apoiada em Arruda et al. (1996)

A falta de estudos que mostrem a economicidade de sistemas alternativos de produção não tem permitido uma melhor indicação sobre a viabilidade de implementação destes sistemas, principalmente no comparativo entre a produção de rosas de corte em campo aberto e em estufas.

Neste sentido, o objetivo deste trabalho é determinar a rentabilidade avaliando as duas alternativas de produção de rosas, da variedade Vegas, em campo aberto e estufa, no Município de Holambra-SP (maior produtora de flores), sob enfoque de análises determinista e de risco (através de simulação de Monte Carlo).

A hipótese básica do estudo é que a utilização de estufas para a produção de rosas de corte na região de Holambra (SP) reduz o risco de produção, produz rosas de melhor qualidade e em maior quantidade (produtividade), propiciando melhor resultado econômico, compensando, temporalmente, o alto investimento de implantação e instalação. 


\subsection{Estrutura do trabalho}

O estudo está dividido em cinco capítulos. O primeiro é a introdução, expondo o problema e sua importância, definindo objetivos e hipóteses que dão sustentação ao estudo. O segundo é uma aproximação do mundo real, visando o conhecimento do sistema de produção de rosas, custos e mercados, que são importantes para a definição de variáveis para o fluxo de caixa dos sistemas propostos.

O terceiro capítulo, trata do material e métodos, descrevendo as fontes de dados, informações sobre a metodologia empregada (cálculo dos índices), pressuposições e limitações do trabalho.

No quarto capítulo, discorre-se sobre os principais resultados obtidos, comparando e analisando as saídas (outputs) para as condições determinista e de risco dos sistemas de produção estudados. No último, apresenta-se as conclusões, sugestões e recomendações para futuros trabalhos no setor de flores. 


\section{CONSIDERAÇÕES SOBRE OS SISTEMAS DE PRODUÇÃO DE ROSAS}

Neste capítulo procura-se descrever algumas características dos sistemas de produção de rosas, custos de produção e estrutura de equipamentos e de mercados (atacadista e varejista), fundamentais à compreensão e geração de subsídios à formulação metodológica a seguir.

\subsection{Vantagens e desvantagens do uso de estufa e algumas tendências}

O uso de estufa modifica o ambiente a fim de favorecer o desenvolvimento das plantas. De acordo com Sentelhas \& Santos (1995), as modificações climáticas são alteradas tanto positiva como negativamente, em alguns aspectos do sistema. Segundo estes autores, a radiação global diminui (de 60 a $80 \%$ da radiação externa, o que diminui a demanda por água para a irrigação) e aumenta a radiação difusa. Esta permite que os raios solares atinjam camadas mais baixas das folhas das plantas, aumentando a fotossíntese. A oscilação da umidade relativa aumenta em estufas, sendo menor que o ambiente externo durante o dia (aumenta o risco de estresse hídrico à planta) e maior durante a noite. A maior umidade relativa durante o período noturno resulta num aumento do período de molhamento das plantas, contribuindo para o desenvolvimento de patógenos causadores de doenças às plantas.

Segundo Kelly (1995), a escolha do tipo de cobertura da estufa deve levar em consideração alguns aspectos como: transparência, custo do material e freqüência com que deve ser mudado. Entre as diversas alternativas de cobertura, a mais empregada é o polietileno de baixa densidade (Sentelhas \& Santos, 1995). Kelly (1995) cita ainda que o 
polietileno de baixa densidade possui baixo custo de aquisição e é fácil de trocar (o próprio produtor pode realizar esta operação). A deterioração deste material é em função da intensidade de raios ultravioletas incidentes: quanto maior a intensidade de raios ultravioletas, menor a vida útil do plástico.

Uma vantagem do uso do plástico é funcionar como cobertura em relação às outras opções, havendo ainda, a possibilidade de se usar plásticos seletivos quanto à passagem de diferentes comprimentos de ondas eletromagnéticas. Por exemplo, existem no mercado tipos de plásticos que diminuem a passagem dos raios infra-vermelhos, possibilitando que a temperatura interna seja menor durante o dia e maior durante a noite (Kelly, 1995). Pode-se adicionar aditivos antigotejantes ao plástico, onde a diminuição do gotejo sobre as plantas evitará injúrias causadas pela água fria e, ainda, diminuiria a umidade durante a noite entre as plantas, refletindo em menor incidência de pragas $\mathrm{e}$ doenças.

Plaisier (1998) sugere o uso de cobertura de aluminet móvel para um melhor controle ambiental. Segundo ele, como o aluminet possui boa reflectância, ele diminuirá, deste modo, a incidência de radiação eletromagnética do interior da estufa, o que promove a diminuição da temperatura durante o dia e aumento desta durante a noite. Assim, além de diminuir a oscilação térmica, também diminuirá a oscilação de umidade relativa, uma vez que a temperatura e a umidade relativa são correlacionadas. Outra vantagem do uso desta alternativa é a proteção às plantas dos raios solares intensos após um período encoberto, onde normalmente ocorre queima das partes mais sensíveis da planta e que é comum sem proteção adequada (apenas plástico).

Outro ponto importante, além do já exposto, é que há uma tendência em países ou regiões onde o custo de mão-de-obra é alto, é a mecanização (Beytes, 1995). A mecanização visa maximizar a estrutura existente, através do aumento da eficiência da mão-de-obra, melhorando a uniformidade e qualidade das plantas. Na Holanda, o uso de robôs, que trabalham praticamente 24 horas por dia, chega a substituir 12 
trabalhadores. Ainda, para aumentar o rendimento da mão-de-obra emprega-se, plantadores e semeadoras automáticas.

Outro aspecto no desenvolvimento de estufas é o controle ambiental mais eficiente. Para Lemons (1999), com o desenvolvimento de hardware e software apropriados vai se tornando mais fácil acompanhar as variações ocorridas no interior das estufas. Estas, com sistemas de refrigeração e aquecimento, podem ter os seus ambientes controlados a partir de modelos de tomada de decisão baseados na temperatura e umidade relativa no interior da estufa. A irrigação controlada, a partir de sensores, também auxilia no controle da umidade relativa.

Com o aprimoramento das câmaras digitais é possivel avaliar a altura das plantas, número de flores e intensidade das cores. É possível usar este sistema no plantio mecanizado, pois, quando há falha, o vaso é automaticamente descartado. A deficiência de nutrientes, o estresse hídrico ou os distúrbios causados pelas altas temperaturas podem ser avaliados por meio destes sensores.

Ademais, os produtores focados na qualidade de gestão, buscam produtos ambientalmente desejados, maiores produções, melhoria na qualidade dos produtos (melhor controle do estado fitopatológico da cultura), acabando por reduzir a quantidade de defensivos químicos. Na Holanda, com o controle biológico, foi possível diminuir em $80 \%$ o uso de defensivos nos últimos 10 anos. Em suma: "o limite da tecnologia na estufa é o dinheiro e a imaginação dos produtores" (Lemons, 1999, p.20).

\subsection{Custo de produção da roseira}

Uma das estratégias citadas para penetrar as rosas em novos mercados, segundo Ecuador (2003), é o aproveitamento das vantagens comparativas e competitivas, que estão relacionadas aos preços de venda do produto. E para produtos tradicionais, caso da rosa, é necessário o desenvolvimento de novas tecnologias para manter a 
competitividade, como é o caso da utilização de estufas para a diferenciação dos produtos.

Segundo Matsunaga et al. (1995), a estrutura do custo de produção entre a produção de rosas em estufa e no campo varia decorrente as diferenças entre os coeficientes técnicos dos dois sistemas e de seus custos de oportunidade. Realizando um estudo de custo de produção de rosas produzidas em estufa, no município de Atibaia, obteve-se o custo de $R \$ 1,10$ por dúzia para uma produtividade de 14 dúzias por metro quadrado, aumentando para $\mathrm{R} \$ 2,21$ por dúzia, se a produtividade alcançada diminuísse para 7 dúzias por metro quadrado. Considerando a distribuição dos possiveis níveis de produção chega-se a um custo médio ponderado de R\$1,52 por dúzia, obtendo-se, deste modo, pela diferença entre o valor de venda da dúzia de rosas e o custo unitário, lucros positivos obtidos apenas se as flores fossem vendidas no período entre abril e dezembro (valores correspondentes a outubro de 2002).

De acordo com Tierra Verde (2002), o custo de produção das rosas colombianas é de US\$ 2,16 por dúzia quando a produtividade média é de 6,25 dúzias por metro quadrado. Quando destinada à Miami-EUA, esta rosa é vendida por US\$ 9,60/dúzia (dólar/2001).

Fisiologicamente, existe uma relação inversa entre a produtividade e o tamanho das hastes. Neste aspecto, Hamrick (1995) cita a experiência de um produtor holandês voltado a produzir rosas de qualidade diferenciada das demais. A produtividade deste roseiral (da variedade Frisco) era de 400 hastes por metro quadrado sendo a produção convencional de 500 a 600 hastes por metro quadrado; porém, no mercado, o valor do produto atingia US\$ 0,24 a US\$ $0,27 /$ haste, enquanto que para os demais os preços de venda variavam entre US\$ 0,14 a US\$ $0,15 /$ haste. Para o floricultor que diferenciou a sua produção, os produtores tradicionais apenas sentem a necessidade de mudar o seu sistema de produção, quando sofrerem prejuízos.

Atualmente, com a globalização do comércio e abertura econômica, caso haja 
uma taxa de câmbio favorável à importação, a competitividade do produto nacional fica prejudicada. Como exemplo tem-se a Argentina que antes do problema de mudanças no câmbio, os produtores detinham $85 \%$ de seu mercado. Com a valorização do peso, o produto importado ganhou o mercado argentino até atingir $70 \%$ do total, com rosas originárias da Colômbia, Equador, Chile e Brasil (Emol, 2002). No Brasil, nos anos seguintes à implantação do Plano Real, quando houve grande valorização da moeda nacional, cresceram as importações de rosas vindas da Colômbia e do Equador, principalmente em datas festivas, como no dia das mães, dos namorados, finados e natal (Matsunaga, 1997).

\subsection{Principais entrepostos de comercialização de flores e plantas ornamentais em São Paulo}

Os principais entrepostos de comercialização de flores e plantas ornamentais no Estado de São Paulo são: CEAGESP, CEASA - Campinas e o Veiling-Holambra. Para Matsunaga (1997), os três centros atacadistas movimentaram, em 1997, cerca de R\$ 267,6 milhões, correspondendo quase à metade das exportações colombianas.

O entreposto mais antigo do Estado de São Paulo é o CEAGESP, inaugurado em 1969 na cidade de São Paulo (Castro, 2002). De acordo com Arruda et al. (1996), as feiras no CEAGESP são realizadas todas as segundas e sextas-feiras, tendo maior movimento de mercadorias nas segundas-feiras. Para estes autores, as transações são realizadas diretamente entre os permissionários e os compradores, que negociam a qualidade, preço e condições de pagamento. É comum o uso de "vales", ou seja, boletos manuais assinados pelo comprador com o valor da compra, sendo que este sistema de pagamento aumenta consideravelmente o risco de inadimplência. Os prazos de pagamentos são longos, promovendo perda financeira por parte do vendedor (permissionário).

Outros problemas citados por Arruda et al. (1996) têm sido a falta de 
padronização e fiscalização das quantidades comercializadas; ausência de manutenção da estrutura física do entreposto; problemas com a segurança das pessoas (violência) e falhas na divulgação das informações (altos custos de informação e comunicação). Com estas deficiências, o sistema de comercialização é lento, o que prejudica a manutenção da qualidade do produto.

O CEASA-Campinas foi inaugurado em fevereiro de 1995 e está localizado em Campinas, na rodovia D. Pedro, próximo às rodovias Anhanguera e Bandeirantes. Os dias de funcionamento ocorrem praticamente durante toda a semana, exceto aos domingos. Os dias de maiores movimentos, são: quinta e segunda-feiras, respectivamente, e, o sistema de venda é praticamente o mesmo do CEAGESP (Arruda et al., 1996).

O Veiling-Holambra pertence à Cooperativa Holambra e está localizado no município de Holambra. O pregão foi inaugurado em 1989 e automatizado em 1991. No Veiling-Holambra, as transações são realizadas através do pregão e também por meio de contratos de venda (vendas por intermediação). De acordo com Salignac (2003), em 2002 , o faturamento deste entreposto foi de $\mathrm{R} \$ 95$ milhões, sendo que $40 \%$ das vendas realizadas por intermediação.

No Veiling, antes do pregão, no dia anterior, o produto é transportado para o recinto onde é classificado de acordo com a sua qualidade $\left(A_{1}, A_{2}\right.$ e $\left.B\right)$ e as flores de corte são armazenadas em câmaras frias até o dia seguinte, quando serão vendidas. Durante o pregão, a ordem da passagem dos lotes dos produtos se dá aleatoriamente, determinada por sorteio. Os preços de venda no pregão são determinados no "Klok" (pregão), iniciando com preço alto e diminuindo gradualmente, até o comprador acionar o botão de compra. A velocidade de transações é, em média, de 1,3 segundo por lote (Salignac, 2003).

Caso nenhum comprador se comprometa à compra do lote antes de atingir o 
preço limite (PLP-preço limite ao produtor), o lote é automaticamente descartado. No descarte, além de perder o produto, são descartadas, também, as embalagens e as caixas, onerando ainda mais o produtor.

O custo de comercialização no Veiling-Holambra é diferenciado, dependendo se o produtor é associado ou não, e pela forma em que o produto é vendido, se intermediação ou pregão ("Klok"). Para um produtor de rosas que é associado, cobra-se sobre o valor de venda $5 \%$ pela prestação do serviço, 2,3\% de FUNRURAL, $1 \%$ de recolhimento para a Cooperativa Central, $1 \%$ para a capitalização do Veiling, $\mathrm{R} \$$ 1,69/carrinho (225 dz) pela emissão de boleto, $\mathrm{R} \$ 0,96 /$ carrinho $(225 \mathrm{dz})$ como taxa do lote e R $\$ 1,80 /$ carrinho ( $225 \mathrm{dz}$ ), como custo de logística pela passagem do carrinho pelo pregão (na venda por intermediação não é cobrada esta taxa). Assim, se o produto for comercializado pelo pregão, o custo de comercialização é 9,3\% sobre o faturamento e mais $\mathrm{R} \$ 4,45 /$ carrinho $(225 \mathrm{dz})$ - valores de outubro de 2002-. Vale observar que o Veiling-Holambra assume o risco de inadimplência no processo de comercialização.

\subsection{Mercado de rosa nos principais entrepostos de São Paulo}

Para Marques (2002), a principal flor comercializada no Estado de São Paulo é a rosa de corte, seguida pelo crisântemo de corte e violeta africana, correspondendo a $30 \%$ da movimentação no CEAGESP, 10\% no CEASA-Campinas (somando 1,6 milhões de dúzias entre 1988 a 2000) e 22\% da receita do Veiling-Holambra.

Entre estes entrepostos o que movimenta maior quantidade de rosas é o VeilingHolambra, correspondendo a 12 milhões de dúzias nos anos de 1999 a 2001. No entanto, é o entreposto que apresenta menores preços médios de venda por dúzia de rosas, enquanto que o CEAGESP é o entreposto que comercializa rosas por preços maiores.

Todos os entrepostos apresentam estacionalidade de preços e de quantidades vendidas. O CEAGESP e o CEASA-Campinas apresentam picos de volumes de vendas 
nos meses de maio e dezembro. Nestes locais, os maiores preços ocorrem a cada 12 meses, sendo os maiores preços em maio, junho e julho. No Veiling-Holambra, os picos de preços também ocorrem a cada 12 meses $^{1} \mathrm{e}$, os de volumes de vendas, se efetuam a cada 3 meses $^{2}$. Estes picos em períodos menores, sugerem que a oferta de rosas de corte no Veiling Holambra é mais regular, o que é desejado para o desenvolvimento de seu mercado (Marques, 2002).

Face a floricultura ser um setor sujeito a riscos e incertezas devido à alta perecibilidade, elevada sensibilidade às pragas e moléstias, às variações climáticas e aos humores do mercado consumidor, o estabelecimento de condições que criem melhor proteção às oscilações do tempo e controle de problemas fitossanitários, tornando os problemas mais uniformes e de conformação requerida pelos consumidores exigentes e, ainda, produtos que tenham maior durabilidade temporal, sem perder as características de qualidade, são os mais desejados. São condições indispensáveis à melhoria da competitividade do produto nacional no mercado mundial e ajustamentos aos gostos e preferências do consumidor internacional.

\footnotetext{
${ }^{1}$ Equação dos preços das rosas comercializadas no Veiling-Holambra, estimada por Marques (2002): $\left(1+0,6018 \mathrm{~B}^{12}\right)(1-\mathrm{B})\left(1-\mathrm{B}^{12}\right) \mathrm{P}_{\mathrm{t}}=(1-0,9206) \mathrm{a}_{4}$

${ }^{2}$ Equação das quantidades de rosas comercializadas no Veiling-Holambra, estimada por Marques (2002): $\left(1+0,8767 \mathrm{~B}^{3}\right)\left(1+0,763 \mathrm{~B}^{6}\right)(1-\mathrm{B})\left(1-\mathrm{B}^{3}\right) \mathrm{V}_{\mathrm{t}}=(1-0,3789 \mathrm{~B})\left(1-0,2915 \mathrm{~B}^{3}\right) \mathrm{a}_{\mathrm{t}}$
}

Onde:

$B=$ Operador de atraso, com $B^{j} V_{t}=V_{t-j}$, o mesmo ocorre com $a_{t}$ e $P_{t}$ sendo o período; Equação dos preços das rosas comercializadas no Veiling-Holambra, estimada por Marques (2002): $\left(1+0,6018 \mathrm{~B}^{12}\right)(1-\mathrm{B})\left(1-\mathrm{B}^{12}\right) \mathrm{P}_{\mathrm{t}}=(1-0,9206) \mathrm{a}_{\mathrm{t}}$

$\mathrm{V}_{\mathrm{t}}=$ Volume comercializado;

$\mathrm{P}_{\mathrm{t}}=$ Preço praticado;

$\mathrm{t}=$ instante de tempo;

$\mathrm{a}_{\mathrm{t}}=$ erro aleatório. 


\section{MATERIAL E MÉTODOS}

O objetivo deste estudo é estabelecer um comparativo sobre indicadores de rentabilidade entre sistemas de produção de rosas de corte, da variedade Vegas, a campo aberto e produção em estufa. A variedade Vegas é produzida nos dois sistemas no Município de Holambra, possuindo botões de coloração vermelha e vigoroso desenvolvimento da planta.

$\mathrm{Na}$ prática, existem diferentes tipos de estufas, porém neste trabalho é analisado a produção de rosas em estufas com estrutura de madeira (eucalipto) por ser um sistema que demanda menor investimento inicial, além de ser considerado a alternativa de mais fácil acesso aos pequenos produtores rurais.

\subsection{Fonte de dados}

Os preços de venda das rosas foram fornecidos pelo Veiling-Holambra, diferenciados por sistema de produção: rosa de campo e rosa de estufa. Os dados são mensais e correspondem a uma dúzia de hastes da variedade Vegas. Os preços não são discriminados segundo a qualidade $\left(\mathrm{A}_{1}, \mathrm{~A}_{2} \mathrm{e} \mathrm{B}\right)$ do produto representando, desta forma, os preços em valores médios. O horizonte temporal de coleta de preços corresponde ao período de janeiro de 1999 a outubro de 2002. Os preços foram corrigidos de acordo com o Índice de Preços ao Consumidor da Fundação Instituto de Pesquisa Econômica (ipc/fipe - obtido no site da fipe), a valores de outubro de 2002. 
Para a elaboração da receita do fluxo de caixa dos projetos, as produções efetivas das roseiras não foram consideradas, mas sim as quantidades vendidas para uma determinada área. Assim, para a elaboração de dados médios de vendas e suas distribuições, partiu-se de relatórios fornecidos pelos produtores, sem distinguir as diferentes qualidades de produto.

Tomou-se o cuidado de coletar dados de vendas apenas de um dado talhão, para cada sistema de produção, isto é, plantas com a mesma idade, apresentando as mesmas condições fisiológicas para a produção.

Os períodos analisados das vendas correspondem a dois anos de produção (segundo e terceiro anos) para ambos os sistemas: estufa e campo. Para cada mês do ano obteve-se a média e os desvios-padrão de vendas. Para ajustar a quantidade vendida (produção) com o ciclo da cultura, multiplicou-se estes dados pelos coeficientes de produção da cultura, que foi fornecido pelos produtores, via entrevista. Por exemplo: para cada sistema, visando ter a estimativa da produção após um ano de produção, multiplicou-se o coeficiente de produção da cultura, quando esta tinha 1 ano ,pela quantidade média vendida no mês de outubro (já que o plantio normalmente ocorre em outubro).

Nas simulações é interessante trabalhar- com os menores períodos possíveis; no entanto, em períodos muito curtos ,o fluxo de caixa da cultura pode apresentar mais períodos de fluxo negativos do que apenas no período inicial, viesando, assim, a determinação da taxa interna de retorno. Desta forma, após serem estimadas as quantidades vendidas mensais para os dois sistemas de produção de rosas de corte, estes dados são transformados para quantidades mínimas (média - menos desvio-padrão), mais provável (média) e máximas de vendas (média mais desvio-padrão) mensais por hectare de produção. Para os cálculos dos índices econômicos, o período indicado é de três meses, com distribuição de probabilidade triangular e spike. 
O gasto em insumos é um dos componentes para a elaboração da planilha de custo. Para o conhecimento das demandas por insumos foram realizadas entrevistas com produtores, encarregados e operários; discriminando-os em: tipo, quantidade e freqüência de utilização de fertilizantes, defensivos, e, freqüência das operações.

Os preços dos insumos foram obtidos no comércio local, desconsiderando as suas possíveis variações. Os valores do transporte de funcionários e das produções das propriedades foram obtidas em empresas especializadas, localizadas no município. Como o valor do transporte de cargas, por carrinho, no município varia em função da quantidade mínima transportada e a presença ,ou não, de rampa na propriedade, considera-se que a necessidade de transporte da produção diária excede dois carrinhos de comercialização (450 dúzias) num ambiente de existência de rampas de cargas.,

Os coeficientes de rendimento das operações que compõem a instalação da cultura, o manejo e condução da mesma, e a pós-colheita foram determinados através de cronometragem de tempo e verificação de rendimentos a campo. A avaliação de demanda por ativos fixos, para os dois sistemas, também foi realizada através de levantamento do inventário em visitas a campo e entrevistas com os produtores.

A obtenção do custo hora/homem no município se deu através do Sindicato dos Produtores Rurais de Holambra, incorporando os encargos trabalhistas. Considerou-se, ainda, um acréscimo no custo horário de mão-de-obra, pelo tempo de deslocamento do trabalhador da cidade à propriedade (em média, 30 minutos diários), tempo este que deve ser remunerado.

Os valores e os tipos de taxas de comercialização de rosas, impostos (não se considerou o imposto de renda e o ITR) e aluguel de carrinhos foram obtidas no VeilingHolambra. Como as taxas de comercialização variam se o fornecedor for associado ou não à Cooperativa Agrícola Holambra, admite-se que os produtores dos dois sistemas 
são associados à cooperativa. E a remuneração dos produtores é o próprio lucro da produção das flores; desta forma, não possuem salário.

Para a determinação do custo de oportunidade do capital, optou-se pela taxa nominal SELIC (obtida no site do Banco Central do Brasil) e corrigida pela taxa de inflação medida pelo ipc/fipe.

\subsection{Modelos matemáticos}

Os modelos matemáticos utilizados são apropriados para a determinação dos indicadores de rentabilidade econômica, fundamentais na aplicação da teoria de investimento em bens de produção. Os indicadores considerados são: relação benefíciocusto (RBC), valor atual (VA), payback simples (PBS), payback econômico (PBE), taxa interna de retorno (TIR), custo total atualizado (CTA) e custo unitário atualizado (CUA). Todos estes índices são calculados para a análise determinista e em condição de risco. $\mathrm{Na}$ análise determinista se trabalha com os valores mais prováveis dos itens que compõem o fluxo de caixa, enquanto que na análise de risco consideram-se os valores mais prováveis e os possíveis desvios que os coeficientes dos fluxos de caixa sofrem.

\subsubsection{Análise determinista}

$\mathrm{Na}$ análise determinista considerou-se os valores médios associados ao uso $\mathrm{e}$ serviços dos fatores de produção constantes no fluxo de caixa (a valores de outubro de 2002). Além de considerar a taxa real SELIC como custo de oportunidade do capital, avaliou - se o desempenho dos projetos às taxas arbitrárias de $20 \%$ e $30 \%$ ao ano, consideradas próximas às taxas de mercados. 


\subsubsection{Relação Benefício-Custo (RBC)}

Este indicador é calculado de acordo com a form. (1). Todos os valores dos benefícios (receitas) e custos, são transformados para o período zero (implantação do projeto). Posteriormente, é obtida a relação entre os benefícios atuais e os custos atuais.

$$
R B C=\left[\sum_{i=0}^{n} B_{i} /(1+\mathrm{j})^{\mathrm{i}}\right] /\left[\sum_{\mathrm{i}=0}^{\mathrm{n}} C_{i} /(1+\mathrm{j})^{\mathrm{i}}\right]
$$

Onde:

$R B C=$ Relação benefício-custo;

$B_{i}=$ Benefício, no período $\mathrm{i}$;

$C_{i}=$ Custo, no período $\mathrm{i}$;

$\mathrm{j}=$ Custo de oportunidade do capital;

$\mathrm{n}=$ número de períodos ou vida útil do projeto.

Este índice é relativamente fácil de interpretação, embora que ,para Azevedo Filho (1988), o mesmo apresenta certas limitações, como a impossibilidade de visualizar a dimensão do projeto e a sua vida útil. A fixação arbitrária do custo de oportunidade do capital também é considerada uma limitação da relação benefício-custo (RBC). A condição de rejeição do projeto se dá quando a relação benefício - custo for menor que 1, ou seja, que após a vida útil do projeto, os custos totais atualizados são maiores que os benefícios atualizados. Assim, caso o investidor adotasse o projeto, a condição de que o indivíduo deixaria de consumir hoje para no futuro ter um consumo maior seria extrapolada.

\subsubsection{Valor Atual (VA)}

$\mathrm{O}$ valor atual nada mais é que um índice que traz para o momento presente o valor das diferenças entre os benefícios e custos atualizados (fluxos de caixa) durante a vida útil do projeto. É calculado através da form. (2). 


$$
V A=\sum_{i=0}^{n}\left(B_{i}-C_{i}\right) /(1+\mathrm{j})^{\mathrm{i}}
$$

Onde:

$V A=$ Valor atual;

$B_{i}=$ Benefício, no período i;

$C_{i}=$ Custo, no período i;

$\mathrm{j}=$ Custo de oportunidade do capital;

$\mathrm{n}=$ número de períodos ou vida útil do projeto.

É um indicador muito valioso para a análise. A vantagem do valor atual (VA) sobre a relação benefício-custo (RBC) é que este tende a ser sensível à escala do projeto. Já as desvantagens seriam a insensibilidade quanto a duração do projeto e a arbitrariedade da taxa de custo de oportunidade do capital.

Hummel \& Tashner (1995) demonstram algumas limitações quando se analisa isoladamente o valor atual, sem considerar a vida útil dos projetos. Poderia ocorrer que um projeto apresente valor atual superior aos demais devido a um maior número de períodos em sua vida útil. Para solucionar este problema, a proposta destes autores seria a adequação de vida útil dos projetos, ou seja, encontrar um mínimo múltiplo comum entre as vidas úteis dos projetos analisados, e desta forma, obter valores atuais mais confiáveis.

A priori, a alternativa de investimento seria descartada quando o valor atual for inferior a zero. Isto indica que, durante a vida útil do projeto, os custos atualizados são maiores que os benefícios atualizados. Nada impede que, se for mudado a vida útil do projeto, o valor atual possa aumentar ou diminuir. 


\subsubsection{3 "Payback" Simples (PBS) e "Payback" Econômico (PBE)}

Estes índices determinam o tempo necessário para que o investidor obtenha novamente os recursos investidos num determinado projeto. Diferenciam entre si, pois o "payback" econômico (PBE) considera o custo de oportunidade do capital, o mesmo não ocorrendo com o "payback" simples (PBS). O payback simples e o payback econômico podem ser determinados pelas form. (3) e (4), respectivamente.

$$
\begin{aligned}
& P B S=K \text { tal que } \sum_{i=0}^{K}\left(B_{i}-C_{i}\right) \geq 0 \text { e } \sum_{i=0}^{K-1}\left(B_{i}-C_{i}\right)<0 \\
& P B E=K \text { tal que }\left[\sum_{i=0}^{K}\left(B_{i}-C_{i}\right) /(1+j)^{i}\right] \geq 0 \text { e }\left[\sum_{i=0}^{K-1}\left(B_{i}-C_{i}\right) /(1+\mathrm{j})^{\mathrm{i}}\right]<0
\end{aligned}
$$

Onde:

$\mathrm{PBS}=$ "payback" simples;

$\mathrm{PBE}=$ "payback" econômico;

$B_{i}=$ Benefício, no período i;

$C_{i}=$ Custo, no período i;

$\mathrm{j}=$ Custo de oportunidade do capital;

$\mathrm{K}=$ número de períodos necessários para recuperar o investimento.

Caso não ocorram as condições expostas nas form. (3) e (4), não existirá "payback" simples e/ou econômico. O projeto seria descartado quando o período necessário para a recuperação do investimento for maior que a vida útil do projeto.

Fleicher (1973) afirma que em ambientes onde há grande incerteza, a escolha de alternativas de menor "payback", ou seja, onde ocorre recuperação mais rápida do capital investido, promove menor exposição do capital a eventos incertos que podem causar prejuízos. Este autor revela que a desvantagem da determinação do payback é a desconsideração do período após a recuperação do capital. 
Para Azevedo Filho (1988), estes indicadores apresentam a característica de auxiliarem na tomada de decisão e não devem ser levados em consideração isoladamente.

\subsubsection{Taxa Interna de Retorno (TIR)}

A taxa interna de retorno assim como os outros indicadores se baseiam no fluxo de caixa estimado do projeto. No caso, determina-se o custo do capital para que o valor atual seja zero. Desta forma, segundo Azevedo Filho (1988), não se depende da arbitrariedade do custo de oportunidade do capital. A taxa interna de retorno deve ser calculada de acordo com a form. (5).

$$
\sum_{i=0}^{n}\left(B_{i}-C_{i}\right) /(1+j)^{i}=0
$$

De modo que:

$\operatorname{TIR}=\mathrm{j}$

Onde:

TIR = Taxa interna de retorno;

$B_{i}=$ Benefício, no periodo i;

$C_{i}=$ Custo, no período i;

$\mathrm{j}=$ Custo de oportunidade do capital;

A escolha do projeto se dá àquele de maior taxa interna de retorno (TIR). São descartados automaticamente os projetos que possuem a taxa interna de retorno menor que o custo de oportunidade do capital considerado e/ou quando os valores forem iguais ou menores que zero. Em trabalho desenvoivido Araújo e Marques (1996), o projeto seria descartado caso a taxa interna de retorno fosse inferior ao custo ponderado do 
capital. Este custo ponderado foi determinado pela média ponderada entre o custo do capital emprestado e custo do capital próprio do investidor.

No entanto, uma das desvantagens do uso da taxa interna de retorno é que esta considera o investimento do capital mutuamente exclusivo, isto é, o empresário não estaria empregando o capital residual em outros projetos.

Fleicher (1973) e Azevedo Filho (1988) recomendam atenção às análises em que o fluxo de caixa apresenta mais de um período com sinal negativo, pois obter-se-ia mais de uma taxa interna de retorno.

\subsubsection{Custo Total Atualizado (CTA)}

O Custo Total Atualizado é um bom índice para expor ao tomador de decisões a grandeza do projeto. Ele pode ser obtido segundo a form. (6).

$$
C T A=\sum_{i=0}^{n} C_{i} /(1+j)^{i}
$$

Onde:

CTA $=$ Custo total atualizado;

$C_{i}=$ Custo, no período i;

$\mathrm{j}$ = Custo de oportunidade do capital;

As limitações que poderiam ser encontradas são as mesmas citadas nos outros indicadores: a arbitrariedade do custo de oportunidade do capital, e a não consideração dos benefícios do projeto. O projeto preferencial é, neste caso, o de menor custo total atualizado. Isto porque o investidor sujeitaria menor parcela de seu capital a riscos e incertezas. Assim, devido às suas restrições, deve-se considerar o custo total atualizado como um indicador auxiliar; por si só não é um indicador conclusivo da melhor alternativa de projeto. 


\subsubsection{Custo unitário atualizado (CUA)}

Embora a avaliação de custo unitário não seja considerada em toda análise de viabilidade econômica de projetos, no presente estudo foi efetuada. Quanto mais próximos os valores dos custos unitários dos valores de venda do produto e maiores desvios, maior será a possibilidade do projeto gerar lucros negativos (prejuízo). É expresso na form. (7).

$$
C U A=C T A /\left[\sum_{i=0}^{n} p_{i} /(1+j)^{i}\right]
$$

Onde:

CUA = Custo unitário atualizado;

CTA = Custo total atualizado;

$p_{i}=$ produção de rosas, no período $\mathrm{i}$;

$\mathrm{j}=$ Custo de oportunidade do capital;

\subsubsection{Análise de risco}

Como as análises de projetos são realizadas anteriormente à sua implantação, o tomador de decisão não possui conhecimento preciso do fluxo de caixa de cada projeto, pois é uma representação "ex-ante". Neste sentido, como tentativa de captar os movimentos de preços e mercados, e dar melhor indicação e credibilidade aos custos e aos benefícios, pode-se valer da mensuração em condições de riscos, via obtenção da função de densidade de probabilidade dos custos e dos benefícios, realizando simulações de variáveis que compõe o fluxo de caixa. Os indicadores nesta análise não são mais pontuais, mas apresentam funções de distribuição e densidade de probabilidade.

O que torna a análise de risco mais confiável é a relação estável ,e empiricamente comprovável, entre o retorno esperado e o risco. Há, portanto, uma dispersão dos possíveis valores do retorno do investimento em torno da sua média (Contador 1975, citado por Chabalin, 1996). 


\subsubsection{Processo de simulação e tomada de decisão em condição de risco}

Neste estudo, o processo de simulação empregado é o de Monte Carlo, que foi desenvolvido por Hertz em 1964 e que apresenta os seguintes passos (Azevedo Filho, 1988):

$1^{\circ}$ ) Identificar a distribuição de probabilidade de cada uma das variáveis relevantes ao fluxo de caixa;

$2^{\circ}$ ) Selecionar, ao acaso, um valor para cada variável, segundo sua distribuição de probabilidade;

$3^{\circ}$ ) Calcular o valor do indicador, toda vez que for feito o "sorteio" mencionado no passo anterior. Toda vez em que é calculado um novo indicador, corresponde a um novo cenário para o projeto;

$4^{\circ}$ ) O número de simulações deve ser suficiente para a obtenção da distribuição da freqüência do indicador, a ponto de se conhecer o formato de distribuição de probabilidade dos indicadores.

O fator fundamental para o sucesso da estimação dos indicadores econômicos é a qualidade dos dados, caso contrário o estudo não se torna confiável ("garbage in, garbage out"). Considerando as limitações em obter-se dados, Azevedo Filho (1988) diz que a distribuição de probabilidade das variáveis ligadas ao fluxo de caixa é, em muitos casos, definida subjetivamente, e é influenciada pela informação disponível ao tomador de decisões.

Obtida a distribuição de probabilidade dos indicadores, o passo seguinte é analisar tais informações, verificando a oportunidade de sucesso ou fracasso do projeto e, ainda, compará-las com as outras alternativas de decisão. Azevedo Filho (1988) discute alguns critérios que devem ser considerados para a tomada de decisão em condição de risco, que são: risco e dimensão do valor obtido (critério de dois parâmetros); critério lexicográfico; e o grau de utilidade esperada. 
Segundo Azevedo Filho (1988), o critério de dois parâmetros, também conhecido como média variância, é o mais discutido na literatura. De acordo com Chabalin (1996), este critério foi desenvolvido por Markovitz, Tobin \& Feldstein, derivado da teoria de decisão de Bernoulli. Considera-se o valor médio e a variância da distribuição do indicador do projeto. Para os investidores avessos a riscos (enquadrando os empresários), a função utilidade apresenta as seguintes propriedades:

$\delta \mathrm{U} / \delta \mathrm{E}(\mathrm{I})>0$

$\delta \mathrm{U} / \delta \operatorname{var}(\mathrm{I})<0$

$\delta \mathrm{U}>0$ se $\delta \mathrm{E}(\mathrm{I}) / \delta \operatorname{var}(\mathrm{I})>0$

Onde:

$\mathrm{U}=$ utilidade do investidor;

$\operatorname{Var}(\mathrm{I})$ = variância do valor do indicador; e,

$\mathrm{E}(\mathrm{I})=$ esperança do valor do indicador;

A form. (8) indica que a variação da utilidade de um determinado tomador de decisões só é positiva quando a variação da esperança do valor do indicador também for positiva, ou seja, o tomador de decisão considera uma situação melhor quando a expectativa do valor médio do indicador for maior. Este critério deve ser considerado para os seguintes indicadores utilizados no presente trabalho: valor atual (VA), relação benefício-custo (RBC) e taxa interna de retorno (TIR), cabendo consideração contrária para os indicadores: payback simples (PBS) e payback econômico (PBE), custo total atualizado (CTA) e custo unitário atualizado (CUA).

Analisando algebricamente a propriedade expressa na form. (9), é possivel visualizar que para haver acréscimo de utilidade para o tomador de decisões, deve-se diminuir a variância do indicador. Corresponde à seguinte interpretação econômica: para o tomador de decisões e/ou investidor o projeto torna-se menos interessante à medida que o risco do mesmo aumenta ou vice-versa. Esta interpretação pode ser considerada para todos os indicadores econômicos. 
Interpretando a form. (10), é possível dizer que o investidor apenas aceita uma condição de maiores riscos se a expectativa do retorno também for maior ou retornos menores quando os riscos forem menores.

O critério lexicográfico ou da máxima probabilidade de sobrevivência, considera um valor crítico para o indicador. De acordo com Azevedo Filho (1988), no caso da taxa interna de retorno (TIR), este valor seria comparado ao custo de oportunidade do capital (por exemplo: a taxa média do rendimento da caderneta de poupança).

Para a utilidade esperada, Azevedo Filho (1988) comenta que seriam necessários estudos prévios para se conhecer o formato da função utilidade do investidor, o que dificulta a utilização deste critério.

\subsubsection{Programa ALEAXPRJ}

É utilizado o programa ALEAXPRJ para as análises determinista e de risco. Este software foi desenvolvido por Azevedo Filho (1988) e tem como recurso a técnica de simulação de Monte Carlo. As possíveis distribuições de probabilidades das variáveis exógenas (as que determinam os índices) podem ser: normais, triangulares, inteira, uniforme e "spike", permitindo a inclusão de até 21 variáveis.

As duas distribuições empregadas no estudo foram a triangular e a "spike". Para a distribuição triangular é preciso conhecer o valor mínimo, o mais provável e o máximo. O seu uso é interessante quando não se tem a quantidade de dados suficientes a conhecer perfeitamente a distribuição de probabilidade da variável. A distribuição "spike" é recomendada em simulações para incorporar risco às variáveis com valores fixos.

A vantagem do uso deste software é o de poupar tempo, pois as simulações que levariam 3 meses de cálculos manuais podem ser obtidas em até 12 horas. A limitação do programa (versão 1.0) além de uso de quantidade limitada de geração de variáveis 
aleatórias, o número de simulações ou cenários é de 1000, para no máximo 100 períodos (Azevedo Filho, 1988).

\subsubsection{Pressuposições e limitações do trabalho}

Considerando a enorme variabilidade de sistema de produção, o tempo e a disponibilidade de dados, tornou-se impossível definir, com precisão, todos os fatores que influenciam o fluxo de caixa. Desta forma, foi necessário recorrer a algumas pressuposições, porém, não fugindo de aproximações reais aos sistemas de produções mais usuais.

A produção real das culturas não é possível conhecer, uma vez que ocorrem perdas a nível de campo (não contabilizadas), devido às características peculiares da floricultura. E estas perdas estão em função da qualidade das hastes e do mercado. Sempre haverá produção de hastes que não atingirá a qualidade mínima para o mercado, e, à medida que o mercado está desaquecido, poderá ocorrer descarte de hastes de melhor qualidade. Em compensação, em datas em que o mercado de flores está mais aquecido haverá maior demanda e aproveitamento da produção.

Desta forma, considerou-se, para a obtenção da receita, o produto entre o preço praticado no entreposto (Veiling) e a quantidade comercializada pelos produtores pesquisados (informações disponíveis em relatórios de venda). Para a comparação entre os projetos, foi convencionado uma área padrão, correspondendo a um hectare (os produtores entrevistados possuem área de produção superior a esta).

Os períodos considerados para a análise determinista e de risco foi de três meses, evitando períodos com fluxo de caixa negativos, a não ser os iniciais. Porém, para tornar a análise de risco mais precisa, simulou-se níveis de produção mensais. Não foi possível trabalhar com valores de vendas mensais, por limitação de geração de variáveis aleatórias do software utilizado (ALEAXPRJ). Os preços corresponderam então aos valores mínimos, mais prováveis e máximos dos períodos: de janeiro/março, abril/junho, 
julho/setembro e outubro a dezembro. A expectativa é que com estes quatro períodos considerados se pudesse captar as diferentes condições sazonais de mercado.

Os efeitos desazonalizados, como o crescimento ou diminuição de mercado só é possível incorporar na análise com o uso de séries históricas longas. De acordo com Navarro, citado por Lopes (2003), o volume de vendas para o Dia das Mães corresponde a $10 \%$ do faturamento anual do Veiling e, para o ano de 2003 , a expectativa de vendas foi de $20 \%$ maior que o ano anterior, sendo a rosa o principal produto comercializado.

Entre os meses de janeiro a março, espera-se menores preços e quantidades vendidas, devido ao periodo de férias escolares, como foi destacado por Marques (2002). O período de abril a junho, tenta captar o efeito sobre as vendas de datas festivas (dias das mãe e dos namorados), que segundo Marques (2002) é possível verificar através de picos altos de quantidades e preços de venda. A partir de agosto os preços tendem a aumentar, principalmente no mês de dezembro com a comemoração do Natal e Ano Novo.

O ciclo da roseira de corte (produção de hastes), varia de acordo com o sistema de produção. Segundo os produtores participantes da pesquisa, o ciclo da cultura no sistema de produção em estufa se estende de 4 a 5 anos e para a produção em campo aberto varia de 6 a 8 anos. Segundo eles, existe uma tendência de diminuir o ciclo da cultura, uma vez que plantas mais novas produzem hastes mais saudáveis e de melhor valor comercial. Desta forma, os ciclos das culturas considerados no presente estudo são: de 4 e 6 anos, para a produção em estufa e em campo aberto, respectivamente.

Para os preços e para as quantidades vendidas as informações disponíveis não foram suficientes para se delinear uma distribuição de probabilidade. Neste caso, assume-se uma distribuição triangular destes fatores, trabalhando-se com os valores mínimos, mais prováveis e máximos. A limitação de dados de produção correspondentes a apenas uma área de produção, e, período inferior a um ciclo de produção, aumenta a imprecisão do estudo. 
Os custos considerados foram divididos em custos fixos e variáveis. Os custos fixos são os gastos que as empresas teriam independentemente da produção, sendo que sua participação no custo unitário diminui à medida que a cultura aumente a sua produtividade e produção (são custos relacionados aos ativos fixos). $\mathrm{Na}$ análise de investimentos, os valores de aquisição dos ativos fixos são considerados no ano zero início da implantação (Hoffmann et al., 1976).

Os cálculos dos valores residuais das estruturas fixas são considerados como venda das mesmas no final do primeiro ciclo de produção (fim do horizonte temporal dos investimentos efetuados) de cada cultura, de acordo com o sistema de produção. Para a produção de rosas de corte em estufa, o valor residual foi de $1 / 3$ do valor da estrutura, isto porque considerou-se 4 anos como ciclo da cultura e a estimativa da vida útil da estrutura fixa é de 12 anos. E o valor residual para a produção de rosas em campo aberto foi de $1 / 3$, onde o ciclo da cultura foi de 6 anos e a estimativa da vida útil da estrutura fixa (discriminado na Tabela 43) é de 18 anos.

É assumido a distribuição spike aos custos, tais como: de investimento em estrutura, custo de oportunidade do valor da terra, de manutenção e administrativos, visando incorporar risco a estes fatores. Aos demais custos, a distribuição apropriada é a triangular.

Como não são conhecidos as funções custos de alguns fatores de produção de acordo com a variação de produção, considerou-se custos variáveis operacionais. Já os custos de colocação de redinhas (para o sistema de estufa), de colheita, de pós-colheita e de comercialização foi possível calculá-los em função da produção.

Os prejuízos com a impossibilidade de venda do produto no entreposto, ou o custo com produto não faturado, são também discriminados para os dois períodos (outubro/março e abril/setembro). Normalmente, no período de mercado mais aquecido o risco de descarte é menor. As quantidades de produtos não faturados basearam-se nos relatórios de venda dos produtores. Estas informações foram transformadas para 
quantidade por área de produção. Considerou-se a distribuição de probabilidade triangular para este fator, considerando a disponibilidade de dados.

Com relação ao uso de simuladores, uma limitação ao uso dos mesmos é a consideração das variáveis que compõem o fluxo de caixa como independentes. Isto faz com que o resultado obtido na análise se distancie das situações reais. Um distorção que pode ocorrer é a geração simultânea de quantidade e preço de venda além da capacidade do mercado, sendo que normalmente ocorre uma correlação negativa entre preço e quantidade de venda.

Fatores ambientais que poderiam influenciar o desempenho econômico dos projetos não foram incorporados ao modelo, por limitação de informação. Para viabilizar a incorporação destas variáveis é necessário longas séries de dados sobre as produções, a qualidade de produção e acompanhamento minucioso dos eventos climáticos, o que não está disponível com um horizonte de tempo apropriado e limitado pela inexistência de órgãos de pesquisa no local das produções.

\subsubsection{Definições e considerações sobre as variáveis no fluxo de caixa}

Para a obtenção das quantidades médias vendidas, bem como suas variações, no ciclo da cultura, partiu-se dos dados fornecidos pelos produtores. Na Tabela 17 do Anexo A, estão listadas as quantidades médias vendidas e seus desvios para o sistema de produção em campo e em estufa, para uma área padrão de um hectare. A quantidade média vendida de rosas de corte, da variedade Vegas, é de 68,04 hastes $/ \mathrm{m}^{2} / \mathrm{ano}$, se produzidas em estufa e, de 34,20 hastes $/ \mathrm{m}^{2} /$ ano quando produzidas a campo aberto. Considerando os espaçamentos da cultura nos diferentes sistemas de produção $(1,28 \mathrm{~m}$ entre linha e 6,5 plantas/m de linha na estufa; e $1,7 \mathrm{~m}$ entre linha e 5 plantas $/ \mathrm{m}$ de linha, em campo aberto), as quantidades produzidas e vendidas correspondem a 13,42 hastes/planta/ano (sistema em estufa), e 11,63 hastes/planta/ano (no campo).

O início da produção é diferente para os dois sistemas, sendo possível colher as primeiras produções para a rosa de estufa a partir do quarto mês após o plantio, enquanto 
que no sistema de campo aberto, após o sexto mês. Para ambas, no final do primeiro ano a produção é de $90 \%$ da capacidade da cultura, atingindo $100 \%$ entre o segundo e o terceiro anos. Depois do terceiro ano, estimou-se que a produtividade do roseiral diminui em 10\% ao ano. Nas Tabelas 19 e 20 estão expostos as produções mínimas, média e máximas mensais dos ciclos dos sistemas de produção de rosas em estufa e campo, respectivamente.

Os dados de preços de venda foram transformados de mensais para trimestrais, através das médias dos valores mínimos, mais prováveis e máximos. Os valores mínimos foram determinados pela diferença dos valores médios do mês com o seu respectivo desvio-padrão. Os valores mais prováveis são os valores médios de venda de cada mês, os valores máximos são a soma dos valores médios com o seu desvio-padrão, como é mostrado na Tabela 18 do Anexo A.

As rosas enviadas ao centro de comercialização e não vendidas são destruídas. Esta medida visa controlar a proliferação de pragas e doenças entre os produtores cooperados ou fornecedores do Veiling. Mesmo sendo uma medida necessária, os produtores sofrem prejuízo com o descarte desta mercadoria. Para efeitos de cálculo deste prejuízo, considerou-se o fluxo de caixa para a colheita, pós-colheita, transporte para cada dúzia de rosa não comercializada.

Com o produto entre o custo unitário dos itens relacionados com as quantidades perdidas para cada sistema obteve-se as Tabelas 37 e 51 . Comparando estes dados é possivel verificar que os valores das perdas, por área, do sistema de produção de rosas de campo são maiores que os das produzidas em estufa. Épocas onde apresentam as principais datas de venda de flores (Dia das Mães, dos Namorados) estes valores diminuem.

Os levantamentos de campo foram tabulados e apresentados como resultados de custos, constituindo o Anexo B, tanto para o sistema de estufa quanto para o sistema de campo. Para cada sistema, considera-se os custos de investimentos em ativos fixos, 
remuneração do terreno, custos de implantação da cultura, custos operacionais que variam e os que não em função da produção, custos de manutenção e administrativos

Como ativos fixos foram considerados os sistemas de irrigação, de pulverização, estrutura de colheita e pós-colheita. E, ainda, para o sistema de produção de rosas em estufa considera-se o investimento na estrutura da estufa e considera-se, ainda, o custo de troca de plástico, dois anos após a construção da estufa (Tabela 29).

O sistema de irrigação varia de acordo com o sistema de produção da roseira. No caso da produção de rosas de campo, o sistema mais utilizado é a irrigação por aspersão devido ao seu custo, menor demanda de capital inicial por área, como pode ser comparado entre as Tabelas 38 (aspersão) e a 24 (sistema localizado de micro-aspersão). Na produção de rosas em estufa evita-se utilizar a irrigação por aspersão para promover melhor controle de umidade relativa do ar e, conseqüentemente, das enfermidades que possam afetar a qualidade e quantidade da produção. Para a produção de campo, o fornecimento de água por aspersão possui ainda a vantagem de limpar as folhas das plantas em períodos secos do ano aumentando a qualidade do produto final.

O sistema de pulverização é o mesmo, tanto para o sistema de produção em campo quanto para o de estufa. Porém, nos casos estudados, como o produtor de rosas de campo possuí maior área plantada, houve um efeito escala sobre os custos de implantação de sistema de pulverização, como mostram as Tabelas 23 e 39, para os sistemas de estufa e campo, respectivamente.

A necessidade de investimento em estufa é exclusivo para o próprio sistema. Considerou-se a demanda de materiais como madeira, parafusos, pregos, etc., pois não existem no mercado local empresas que vendam estufas de estruturas de madeira prontas, devendo o produtor, primeiro adquirir o material para a construção e depois contratar os construtores, que cobram por área construída. Os gastos necessários para a construção de um hectare de estufa de madeira (eucalipto) são encontrados na Tabela 22, do Anexo B. A vida útil média da estrutura da estufa é estimada pelos produtores em 12 anos. 
A estrutura de pós-colheita varia mais em relação à escala de produção de rosas do que pelo sistema de produção em si. No caso do produtor de rosas de campo, como o seu campo de produção se estende por 15 hectares, é então viável possuir um parque de pós--colheita com maquinas mais modernas, automatizando parte do processo. As diferentes necessidades de investimentos estão disponibilizados nas Tabelas 26 e 41 (Anexo B).

Os custos de preparo de solo e implantação da cultura são distintos entre os diferentes sistemas de produção. No caso da produção de rosas de campo após a subsolagem, a operação seguinte é a gradagem com uso de grade aradora, enquanto que no sistema de produção em estufa são usados a pá rotativa e a enxada rotativa. $\mathrm{O}$ modo em que são preparados os sulcos de plantio também é próprio para cada sistema. Para as roseiras de campo os sulcos são abertos por um sulcador tracionado por um trator, e no sistema de estufa os sulcos são abertos manualmente com o auxílio de uma enxada. Os custos de implantação estão dispostos nas Tabelas 33 e 47 para os sistemas de estufa e campo, respectivamente.

A correção de solo e a adubação variam de acordo com o produtor. Os maiores cuidados no que se refere a este tema, é que os adubos usados no sistema de produção em estufa são especiais (menos salinos). Isto se deve ao diferente regime hídrico existente no interior da estufa que favorece a salinização do solo.

Von Drathen (1990) descreve algumas soluções quando o solo apresentar este tipo de problema. A acidez do solo é corrigida antes da implantação da cultura nos dois casos estudados. Porém, o controle da acidez se difere após a implantação. No caso da rosa de campo aplica-se calcário a cada ano e, no sistema de estufa, o controle é feito com a alternância de diferentes tipos de adubos, usando os ácidos quando o solo estiver com o $\mathrm{pH}$ alto e os alcalinos quando o solo estiver ácido.

Após a implantação, as demais despesas são contabilizadas como custos variáveis. Entre os custos variáveis tem-se o custo de manutenção. Este é dividido em manutenção do sistema de irrigação, pulverização, colheita e pós-colheita. A 
manutenção do sistema de pós-colheita (câmara fria) é terceirizado, as demais manutenções são realizadas pelos próprios funcionários da empresa. Estes custos de manutenção e os custos administrativos encontram-se nas Tabela 32 para o sistema de estufa e 46 para o sistema de campo (Anexo B).

Os custos operacionais dizem respeito aos gastos com a execução das operações e com insumos para a manutenção da cultura. Nas operações de manejo da cultura, a maior diferença entre os sistemas é o controle de plantas daninhas. No campo, a partir do terceiro semestre o controle das plantas daninhas se dá pelo uso de roçadeiras nas entrelinhas, herbicidas e/ou capinas na linha. No sistema de estufa, é usada uma micro enxada rotativa na entrelinha e, capina manual, na linha. Os dados estão na Tabela 34 para o sistema de estufa e Tabela 48 para o sistema de campo (Anexo B).

O sistema de colheita varia de produtor para produtor. No caso estudado, o produtor de rosas de campo trabalha com o método tradicional de colheita, onde os funcionários cortam as hastes com uma tesoura especial e as seguram nos braços. Quando percorrido certa distância nas linhas de cultivo, existem carreadores que as levam às casinhas, que são pontos de coleta de rosas no campo, sendo colocadas em baldes. O número de hastes que o trabalhador deposita por vez, no balde, varia de $120 \mathrm{a}$ 160. No fundo de balde há água $(20 \mathrm{~cm})$, para hidratar as flores e aumentar a sua vida de vaso. De tempo em tempo, um trator com carreta passa na lavoura para recolher a produção e repor os baldes vazios no campo. Os gastos para a colheita, pós-colheita e comercialização para o sistema de campo aberto estão na Tabela 49.

No caso do produtor de rosa de estufa, o mesmo tem optado por um sistema de colheita distinto. A forma como as hastes são cortadas é a mesma, porém após serem cortadas as hastes são dispostas em caixas de plástico, visando minimizar os ferimentos. Isto porque os ferimentos nas hastes promovem aumento da taxa de respiração e acelera a sua deterioração. Para executar esta operação o rendimento linear de colheita é afetado. Para amenizar este problema introduziu-se a técnica de produção de rosas com uso de redinha, o qual possibilita a colheita em dias alternados, o que aumenta a quantidade de 
hastes a serem colhidas por metro linear, melhorando o desempenho do trabalhador (hastes/hora). Os custos para a colocação de redinhas, futuros ajustamentos na flor, a colheita, pós-colheita e comercialização das rosas são apresentados na Tabela 35. 


\section{RESULTADOS E DISCUSSÃO}

Este capítulo traz os resultados do comparativo estabelecido para a análise de investimentos em bens de produção de rosas nos sistemas de campo e de estufa, em situação determinista e em condição de risco. As análises da sensibilidade dos índices econômìcos em relação à variação dos itens que compõe de custos e benefícios foram determinados através de análise determinista a seguir.

\subsection{Análise determinista}

$\mathrm{Na}$ determinação dos índices econômicos procurou-se trabalhar com os menores períodos visando minimizar o efeito da geração de dados aleatórios no simulador, principalmente para a análise de risco. No entanto, com períodos mais curtos, aumentase a possibilidade de haver outros períodos, além dos iniciais, com fluxos de caixa negativos, o que tornaria viesado o índice taxa interna de retorno (TIR).

Desta forma, para os casos em estudo, os períodos considerados foram trimestrais. As Tabelas 3 e 4 mostram de forma compacta e sintetizada os fluxos de caixa para o sistema de produção de rosas em estufa e as Tabelas 5 e 6 para o sistema de produção a campo. Para os projetos obteve-se apenas os dois períodos iniciais com fluxo de caixa negativo, viabilizando a obtenção de uma única taxa interna de retorno (TIR), fundamental para a análise comparativa.

Os valores residuais em ambas as tabelas provêm da venda da estrutura fixa, investimento inicial e que hipoteticamente seriam disponibilizados para a venda (receita) ao final da vida útil econômica dos projetos. Como a vida útil da estrutura da estufa é de 
12 anos, o valor residual para 1 ciclo da cultura (4 anos ou 16 trimestres) é de $2 / 3$. A mesma fração é esperada para os demais ativos fixos do sistema de produção em campo já que a vida útil esperada é de 18 anos e o período de um ciclo da cultura nestas condições é de 6 anos ou 24 trimestres.

Os custos não faturados são os custos com as rosas enviadas ao centro de comercialização (Veiling Holambra) e não comercializados. Já os custos que variam em função da produção são: os custos com colheita, pós-colheita e comercialização. Para o sistema de produção em estufa, considera-se, ainda, a colocação e ajustamento de redinhas de proteção das flores. E os custos operacionais são os gastos para a manutenção da cultura, tornando-as produtivas. Para o custo de implantação considerase o preparo do solo e a implantação da cultura.

Tabela 3. Fluxo de caixa trimestral, entre os períodos 0 e 7 , para a produção de rosas de corte no sistema de produção em estufa, no Município de Holambra - SP.

\begin{tabular}{|c|c|c|c|c|c|c|c|c|}
\hline \multirow[t]{2}{*}{ Fluxo de caixa } & \multicolumn{8}{|c|}{ PERIODOS (Trimestrais) } \\
\hline & 0 & 1 & 2 & 3 & 4 & 5 & 6 & 7 \\
\hline \multicolumn{9}{|l|}{ A) Custos } \\
\hline Investimento & $109.667,67$ & - & - & - & - & - & - & - \\
\hline Implantação & $17.347,79$ & - & - & - & - & - & - & - \\
\hline Adm./manut. & 969,99 & 969,99 & 969,99 & 969,99 & 969,99 & 969,99 & 969,99 & 969,99 \\
\hline Operacional & $7.428,36$ & $7.428,36$ & $7.428,36$ & $7.428,36$ & $7.428,36$ & $7.428,36$ & $7.428,36$ & $7.428,36$ \\
\hline Função da prod. & 256,92 & $4.397,94$ & $5.872,32$ & $7.409,96$ & $9.440,22$ & $14.032,37$ & $9.850,10$ & $8.383,25$ \\
\hline Comercialização & 77,65 & $1.240,66$ & $3.322,26$ & $3.721,28$ & $2.853,31$ & $3.958,53$ & $5.572,69$ & $4.210,07$ \\
\hline Plástico & - & - & - & - & - & - & - & - \\
\hline Não Faturado & - & 278,76 & 82,50 & 82,50 & 278,76 & 278,76 & 82,50 & 82,50 \\
\hline TOTAL & $135.748,38$ & $14.315,71$ & $17.675,43$ & $19.612,10$ & $20.970,64$ & $26.668,17$ & $23.903,64$ & $40.753,28$ \\
\hline \multicolumn{9}{|l|}{ B) Benefícios } \\
\hline Receita Bruta & 834,99 & $13.340,42$ & $35.723,28$ & $40.013,82$ & $30.680,73$ & $42.564,87$ & $59.921,43$ & $45.269,54$ \\
\hline Valor residual & - & - & - & - & - & - & - & - \\
\hline TOTAL & 834,99 & $13.340,42$ & $35.723,28$ & $40.013,82$ & $30.680,73$ & $42.564,87$ & $59.921,43$ & $45.269,54$ \\
\hline \multicolumn{9}{|l|}{ C) Fluxo Líquido } \\
\hline Diferencial (A-B) & $-134.913,00$ & $-975,30$ & $18.047,84$ & $20.401,72$ & $9.710,09$ & $15.896,85$ & $36.017,79$ & $4.516,25$ \\
\hline
\end{tabular}

Nota: Valores expressos em reais de outubro de 2002. 
Tabela 4. Fluxo de caixa trimestral, entre os períodos 8 e 15, para a produção de rosas de corte no sistema de produção em estufa, no Município de Holambra - SP.

\begin{tabular}{|c|c|c|c|c|c|c|c|c|}
\hline \multirow[b]{2}{*}{ Fluxo de caixa } & \multicolumn{8}{|c|}{ PERIOODOS (Trimestrais) } \\
\hline & 8 & 9 & 10 & 11 & 12 & 13 & 14 & 15 \\
\hline \multicolumn{9}{|l|}{ A) Custos } \\
\hline Investimento & - & - & - & - & - & - & - & - \\
\hline Implantação & - & - & - & - & - & - & - & - \\
\hline Adm./manut. & 969,99 & 969,99 & 969,99 & 969,99 & 969,99 & 969,99 & 969,99 & 969,99 \\
\hline Operacional & $7.428,36$ & $7.428,36$ & $7.428,36$ & $7.428,36$ & $7.428,36$ & $7.428,36$ & $7.428,36$ & $7,428,36$ \\
\hline Função da prod. & $10.213,80$ & $14.773,80$ & $10.119,00$ & $8.372,43$ & $9.965,99$ & $14.037,85$ & $9.376,00$ & $4.807,33$ \\
\hline Comercialização & $3.087,12$ & $4.167,69$ & $5.724,82$ & $4.204,64$ & $3.012,22$ & $3.960,08$ & $5.304,47$ & $2.414,24$ \\
\hline Plástico & & $19.679,12$ & - & - & - & - & - & $19.679,12$ \\
\hline Não Faturado & 278,76 & 278,76 & 82,50 & 82,50 & 278,76 & 278,76 & 82,50 & 82,50 \\
\hline TOTAL & $21.978,03$ & $27.618,60$ & $24.324,67$ & $21.057,92$ & $21.655,33$ & $26.675,03$ & $23.161,32$ & $35.381,54$ \\
\hline \multicolumn{9}{|l|}{ B) Benefício } \\
\hline Receita Bruta & $33.194,85$ & $44.813,86$ & $61.557,25$ & $45.211,14$ & $32.389,49$ & $42.581,47$ & $57.037,34$ & $25.959,59$ \\
\hline Valor residual & - & - & - & - & - & - & - & $73.111,78$ \\
\hline TOTAL & $33.194,85$ & $44.813,86$ & $61.557,25$ & $45.211,14$ & $32.389,49$ & $42.581,47$ & $57.037,34$ & $99.071,37$ \\
\hline \multirow{2}{*}{\multicolumn{9}{|c|}{ C) Fluxo Líquido }} \\
\hline & & $17.195,26$ & $37.232,58$ & $24.153,22$ & $10.734,16$ & $15.906,43$ & $33.876,02$ & $63.689,83$ \\
\hline
\end{tabular}

Nota: Valores expressos em reais de outubro de 2002.

Através destes fluxos de caixa, para os diferentes sistemas, calculou-se os índices: taxa interna de retorno (TIR), relação benefício-custo ( $R B C$ ), custo total atualizado (CTA), valor atual (VA), payback simples e payback econômico. Avaliou-se os projetos considerando diferentes custos de oportunidade do capital: de 10,2\% ao ano, que é a média aritmética da taxa Over Selic do período (de janeiro de 1999 a setembro de 2002); $20 \%$ e $30 \%$ ao ano, que são valores arbitrários supondo-se como aproximações às taxas prevalecentes no mercado.

Os resultados dos cálculos deterministas, através do ALEAXPRJ, estão expostos nas Tabelas 7, 8 e 9, para os sistemas de produção de rosas a campo, em estufa e em estufa com o custo em função da produção do sistema de campo, respectivamente. Os projetos são economicamente viáveis, por possuírem taxas internas de retorno acima dos custos de oportunidade do capital considerados e valores atuais maiores que zero, relações benefício-custo maiores que um, e payback simples e econômico menores que as vidas úteis dos projetos. 


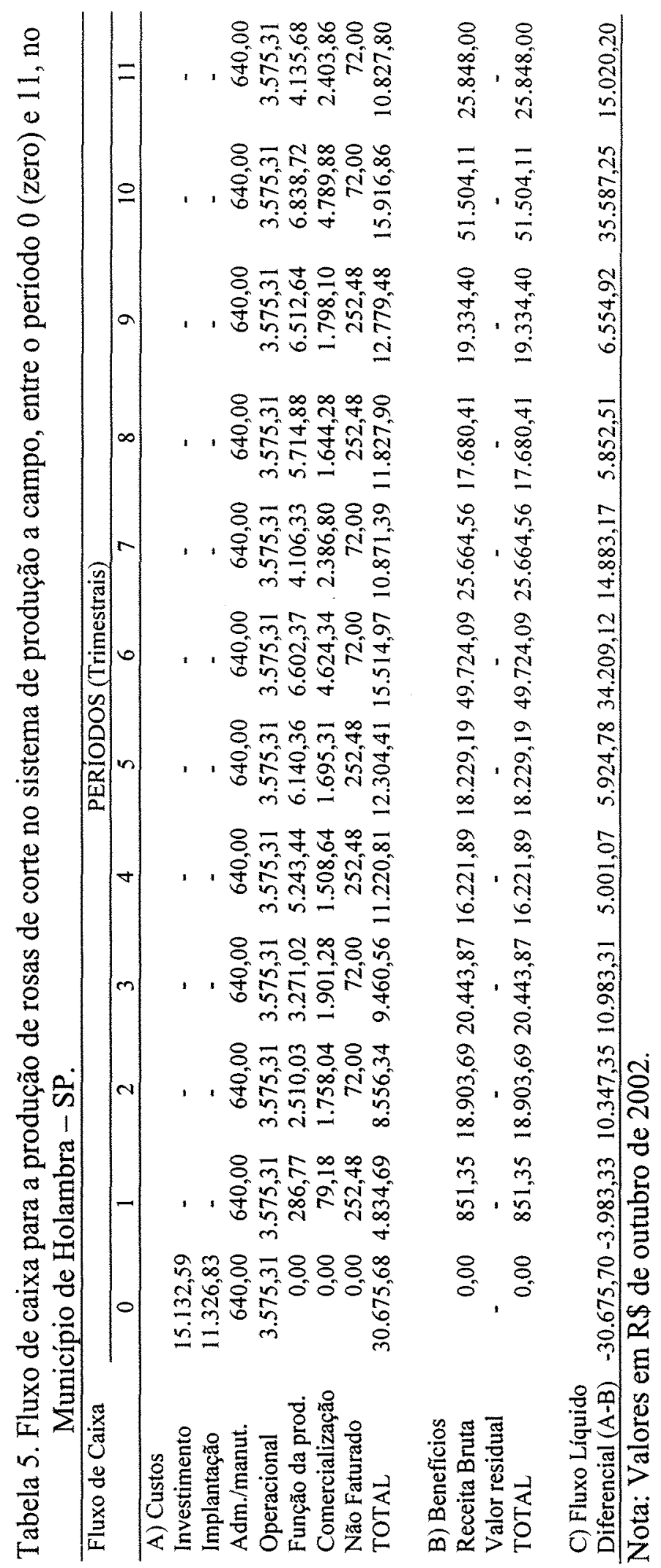




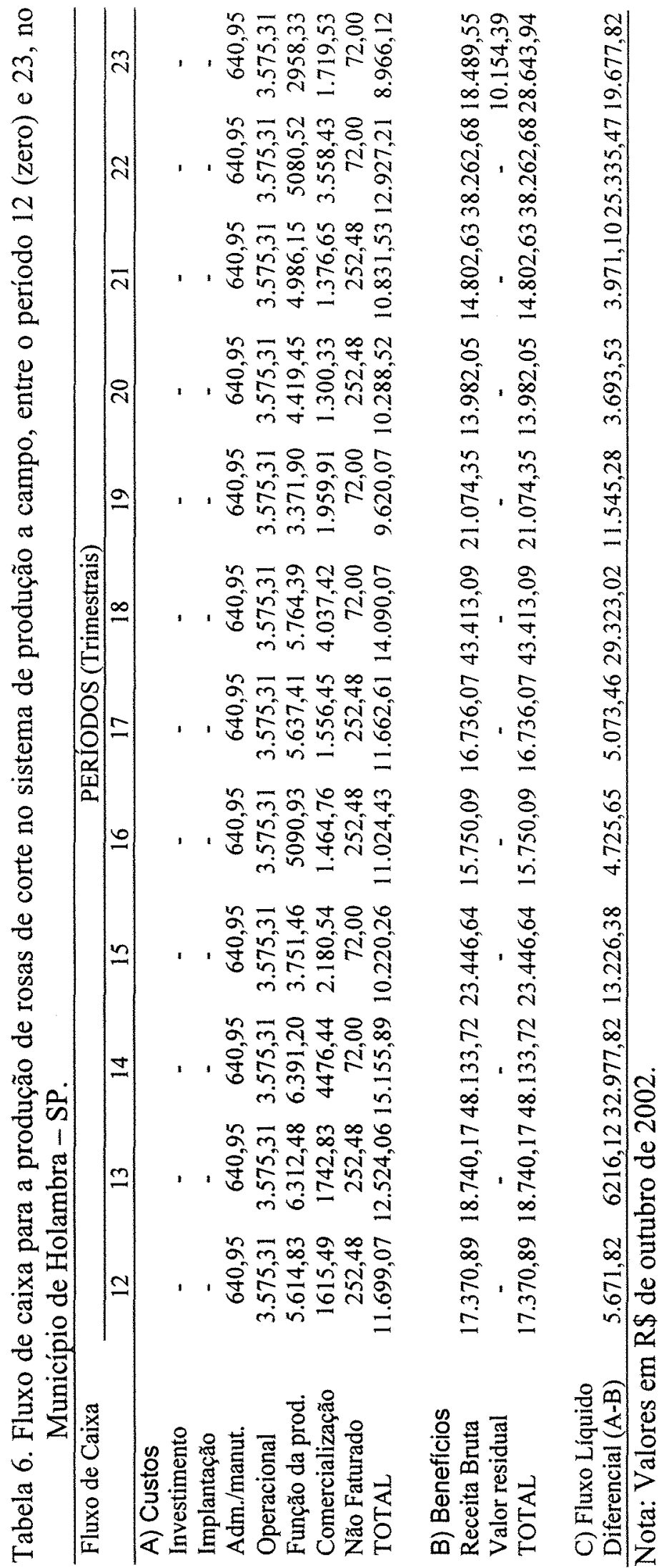


Tabela 7. Análise determinista do sistema de produção de rosas em campo, da variedade Vegas, no Município de Holambra.

\begin{tabular}{lrrr}
\hline & \multicolumn{3}{c}{ Custo de oportunidade do capital } \\
\cline { 2 - 4 } Indicadores & $10,2 \%$ & $20,0 \%$ & $30,0 \%$ \\
\hline Taxa interna de retorno (TIR) - \% a. a. & 57,91 & 57,91 & 57,91 \\
Relação beneficio-custo (RBC) & 1,320 & 1,245 & 1,170 \\
Valor atualizado (VA) - R $\$$ & $53.952,04$ & $34.379,09$ & $20.310,21$ \\
Custo total atualizado (CTA) - R\$ & $168.142,77$ & $140.211,18$ & $119.765,81$ \\
Payback Simples (PBS) - anos & 2,50 & 2,50 & 2,50 \\
Payback econômico (PBE) - anos & 2,50 & 2,50 & 2,50 \\
Custo unitário atualizado (CUA) - R $\$ / \mathrm{dz}$ & 1,306 & 1,376 & 1,457 \\
\hline
\end{tabular}

Nota: Valores expressos em reais de outubro de 2002.

Comparando os resultados apresentados nas Tabelas 7 e 8 , verifica-se que o sistema de produção de rosas da variedade Vegas à campo apresenta indicadores econômicos mais favoráveis. A taxa interna de retorno (TIR) para o sistema de campo aberto é de $57,91 \%$ ao ano, enquanto que para o sistema de estufa é de $50,17 \%$ ao ano. Este índice apresenta a vantagem da não arbitrariedade dos custos de oportunidade do capital.

O valor atual (VA), que é a diferença entre o beneficio total atualizado e custo total atualizado, é de $R \$ 133.183,46$ para o sistema de estufa e $R \$ 53.952,04$ para o campo. Aparentemente, estes dados mostram uma vantagem da opção de produção em estufa. Porém, ao fazer a relação do benefício total atualizado com o custo total atualizado, obtém se a relação benefício-custo, que é de 1,32 para o sistema de campo e 1,307 para estufa. Pode-se então dizer que para cada $R \$ 1,00$ investido em cada sistema, a expectativa é de obter $\mathrm{R} \$ 0,32$ de retorno quando investido na produção de rosas à campo e $\mathrm{R} \$ 0,31$ em estufa, a $10,2 \%$ ao ano de custo de oportunidade do capital.

O custo total atualizado (CTA) para um hectare de produção de rosas em estufa é de $R \$ 434.518,34$ e a de campo é de $R \$ 168.142,77$, a uma taxa de $10,2 \%$ ao ano. Este índice evidencia a utilização mais intensiva de capital no sistema de estufa, revelados pelos gastos em estrutura fixa e gastos de produção. 
Os períodos de recuperação de capital de investimento, medidos pelos payback simples e econômico, são praticamente os mesmos (2,5 anos) para as duas opções. Variam apenas para a estufa, quando o custo de oportunidade do capital é de 20 e $30 \%$ ao ano, explicados, provavelmente, pela maior demanda de capital para a produção. Embora nominalmente os valores sejam iguais ou próximos, as relações dos paybacks com as vidas úteis dos projetos é favorável à produção à campo, já que esta apresenta uma vida útil de 6 anos e, para o sistema de estufa, é de 4 anos.

Apesar do sistema de produção de rosas em estufa apresentar uma maior produtividade por área, o que diminui o valor dos custos fixos por unidade produzida, o seu custo unitário atualizado da dúzia de rosas variedade Vegas é de $\mathrm{R} \$ 2,26$ se produzida em estufa e a produção à campo é de $R \$ 1,31$. O valor médio de venda do sistema de produção de rosas em estufa é $17 \%$ maior que seu custo, enquanto que para o sistema de campo é de $22 \%$ revelando que, quanto maior esta diferença menor é o risco de prejuízos.

Tabela 8. Análise determinista do sistema de produção de rosas em estufa, da variedade Vegas, no Município de Holambra.

\begin{tabular}{lrrr}
\hline & \multicolumn{3}{c}{ Custo de oportunidade do capital } \\
\cline { 2 - 4 } Índicadores & $10,2 \%$ & $20,0 \%$ & $30,0 \%$ \\
\hline Taxa interna de retorno (TIR) - \% a. a. & 50,17 & 50,17 & 50,17 \\
Relação beneficio-custo (RBC) & 1,307 & 1,21 & 1,136 \\
Valor atualizado (VA) - R $\$$ & $133.183,46$ & $84.916,94$ & $47.370,75$ \\
Custo total atualizado (CTA) - R $\$$ & $434.518,34$ & $386.992,62$ & $349.215,74$ \\
Payback Simples (PBS) - anos & 2,50 & 2,50 & 2,50 \\
Payback econômico (PBE) - anos & 2,50 & 2,75 & 3,25 \\
Custo unitário atualizado (CUA) - R $\$ / \mathrm{dz}$ & 2,265 & 2,395 & 2,541 \\
\hline
\end{tabular}

Nota: Valores expressos em reais de outubro de 2002.

Avaliando as Tabelas 7 e 8 , os resultados indicam que o sistema de campo é preferível em relação à produção de rosas de corte em estufa, o que contraria a tendência observada de crescimento de área produzida em estufa. Entretanto, é necessário recordar que este trabalho trata de um estudo de casos, apresentando assim todas as limitações deste tipo de estudo, ou seja, a falta de representatividade. 
Outro aspecto é que, além da opção da utilização - ou não - de estufa para a produção de rosas, há também distintos procedimentos de condução da cultura, desde os tratos culturais até o uso de redinhas de proteção dos botões e diferente processo de colheita. O ganho qualitativo obtido por estes diferentes procedimentos está embutido no valor de venda que cada produtor obtém ao comercializar o seu produto. Como os preços utilizados neste estudo são os preços médios de venda no Veiling, este ganho qualitativo não é contabilizado.

Para evitar conclusões errôneas, se a utilização de estufa é mais indicado ou não para a produção de rosas, no Município de Holambra, calculou-se novamente os indicadores de rentabilidade econômica considerando o custo de colheita e pós-colheita no caso do produtor de rosas de campo, não utilizando redinhas de proteção dos botões.

Nesta nova situação (Tabela 9), os indicadores econômicos apontam a utilização de estufa como a alternativa mais rentável. A sua taxa interna de retorno passou de $50,17 \%$ ao ano para $66,54 \%$ a.a., sendo maior que os $57,91 \%$ a.a. do sistema de campo aberto. A relação benefício-custo saltou de 1,307 para 1,491, à 10,2\% a.a. de custo de oportunidade do capital. O período de recuperação do capital também diminui, sendo, neste caso, de 1,75 anos (Payback simples) e de 2,00 a 2,5 anos (Payback econômico).

Quanto a variação dos indicadores à variação do custo de oportunidade do capital, não muda a situação de melhor eficiência econômica para o caso de cultivo de rosas à campo aberto. As rentabilidades das duas alternativas de produção de rosas de corte diminuem com o aumento do custo do capital. 
Tabela 9. Análise determinista do sistema de produção de rosas em estufa, considerando o custo em função da produção do caso do sistema de produção em campo, da variedade Vegas, no Município de Holambra.

\begin{tabular}{lrrr}
\hline & \multicolumn{3}{c}{ Custo de oportunidade do capital } \\
\cline { 2 - 4 } Índicadores & $10,2 \%$ & $20,0 \%$ & $30,0 \%$ \\
\hline Taxa interna de retorno (TIR) - \% a. a. & 66,54 & 66,54 & 66,54 \\
Relação benefício-custo (RBC) & 1,491 & 1,381 & 1,276 \\
Valor atualizado (VA) - R\$ & $186.888,98$ & $130.165,01$ & $85.852,74$ \\
Custo total atualizado (CTA) - R $\$$ & $380.812,81$ & $341.744,55$ & $310.733,76$ \\
Payback Simples (PBS) - anos & 1,75 & 1,75 & 1,75 \\
Payback econômico (PBE) - anos & 2,00 & 2,50 & 2,50 \\
Custo unitário atualizado (CUA) - R $\$ / \mathrm{dz}$ & 1,985 & 2,115 & 2,261 \\
\hline
\end{tabular}

Nota: Valores expressos em reais de outubro de 2002.

$\mathrm{Na}$ Tabela 10 é possível avaliar melhor as alterações dos índices de rentabilidade em relação à variação do custo do capital. $\mathrm{O}$ valor atual dos projetos é o mais sensível dos indicadores à alteração do custo de oportunidade do capital. Isto, provavelmente, se dá pelo maior peso da receita e pela concentração da mesma em períodos mais distantes aos iniciais. Como o projeto de produção em estufa demanda proporcionalmente mais capital em seu período inicial, o seu custo total atualizado é menos sensível às variações do custo de capital.

Tabela 10. Variação percentual dos indicadores à variação do custo de oportunidade do capital.

\begin{tabular}{lcccc}
\hline & \multicolumn{2}{c}{ Estufa } & \multicolumn{2}{c}{ Campo } \\
\cline { 2 - 5 } Indicadores & $10,2 \%-20 \%$ & $20 \%-30 \%$ & $10,2 \%-20 \%$ & $20 \%-30 \%$ \\
\hline Relação benefício-custo (RBC) & $-7,42$ & $-6,12$ & $-5,68$ & $-6,02$ \\
Valor atual (VA) & $-36,24$ & $-44,22$ & $-36,28$ & $-40,92$ \\
Custo total atualizado (CTA) & $-10,92$ & $-9,76$ & $-16,61$ & $-14,58$ \\
Payback econômico (PBE) & 10,00 & 18,18 & 0,00 & 0,00 \\
Custo unitário atualizado (CUA) & 5,74 & 6,10 & 5,36 & 5,89 \\
\hline
\end{tabular}

A análise determinista possibilita ainda avaliar a variação da rentabilidade dos projetos às variações de alguns custos. Este teste se chama análise de sensibilidade. É importante pois possibilita determinar os pesos que cada variável do fluxo de caixa na rentabilidade das alternativas examinadas. A análise de sensibilidade está exposta nas Tabelas 11 e 12, para os casos de produção de rosas em estufa e a campo, respectivamente. 

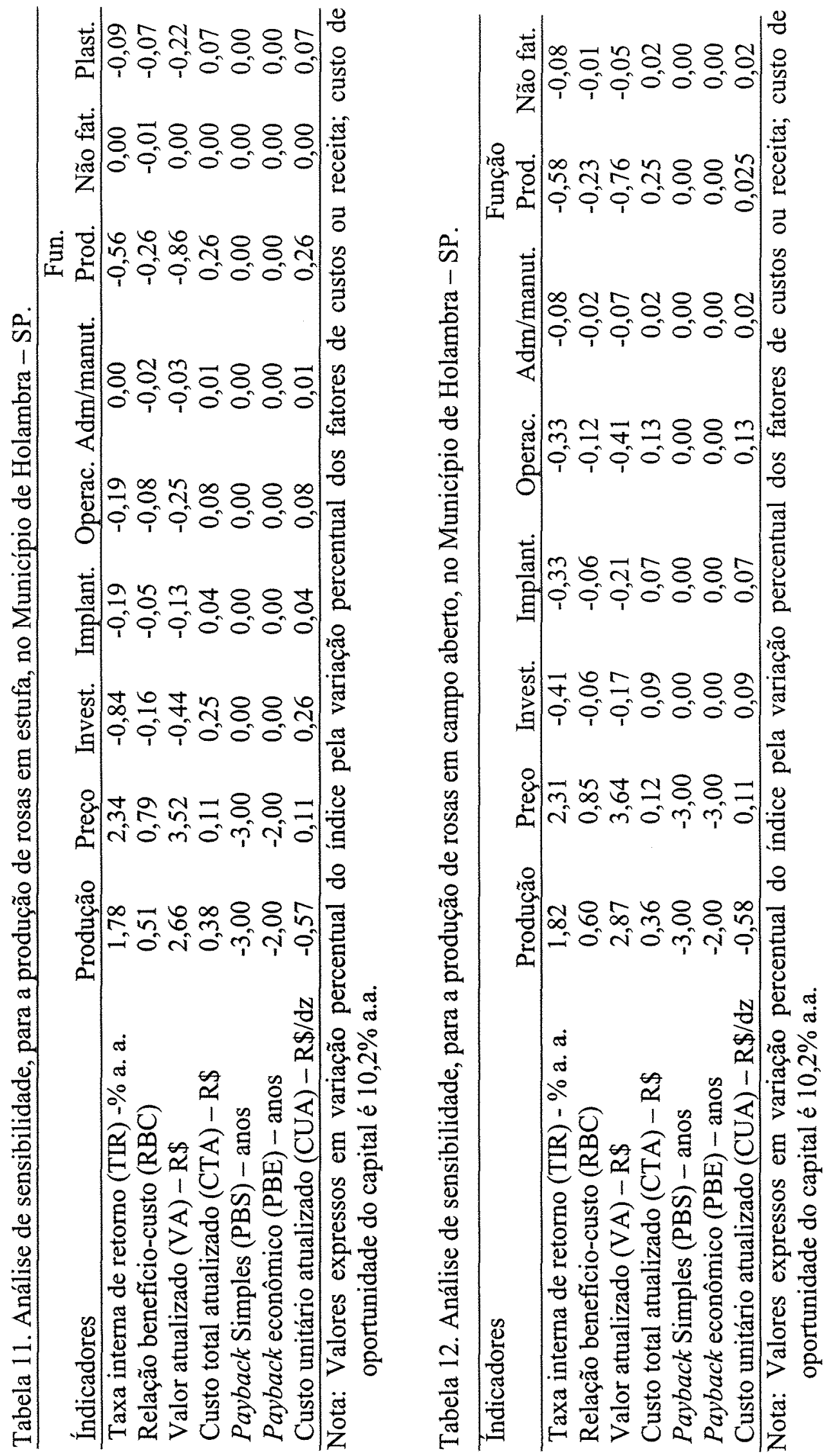
Os valores indicados nas Tabelas 11 e 12 são expressos em termos de elasticidade. Apresenta a variação percentual do indicador econômico à variação de $1 \%$ da variável de fluxo de caixa. De forma geral, as variáveis de receita influenciam mais a rentabilidade do projeto que às de custo. Ambos os projetos são mais sensíveis às variações de preços do que às variações de produção (vendas), sendo a produção a segunda variável que mais altera a rentabilidade dos projetos. $\mathrm{O}$ aumento das vendas, para uma dada área, diminui o custo da dúzia de rosa, porque os custos fixos são "diluídos" numa maior produção, enquanto que o aumento do preço de venda das rosas aumenta o custo unitário, devido ao custo de comercialização por unidade vendida.

A variação da rentabilidade dos projetos em relação à variação dos custos é menor que as variações de receita, em geral, se alguma destas variáveis alterar em 1\%, a variação da rentabilidade será menor que $1 \%$. O custo que menos peso apresenta na variação de rentabilidade é o custo não faturado, correspondente aos gastos com os lotes de rosas enviados ao centro de comercialização e que não foram vendidos.

O custo determinado pela produção (colocação de redinhas, colheita e póscolheita) é o que mais afeta os valores dos indicadores econômicos, especialmente a taxa interna de retorno (TIR). O investimento em estrutura fixa é o segundo fator que mais altera a rentabilidade dos projetos, provavelmente, porque o investimento em estrutura fixa para a produção em estufa corresponde a $25 \%$ em relação ao custo total atualizado, enquanto o mesmo investimento em estrutura fixa, do sistema de campo, é de apenas $9 \%$ em relação ao custo total atualizado.

$\mathrm{O}$ índice econômico mais sensível às variações do fluxo de caixa foi o valor atual (VA), seguido pelos paybacks simples e econômico, taxa interna de retorno (TIR), relação benefício-custo (RBC), custo unitário atualizado (CUA) e, por fim, o custo total atualizado (CTA). 


\subsection{Análise de Risco}

A análise de risco é uma análise mais interessante que a análise determinista por considerar as possíveis variações dos fatores que compõem o fluxo de caixa. Os resultados não são pontuais como na análise determinista que podem ser viesados dependendo dos preços considerados, ainda mais se forem tomados em fase de oferta reduzida e demanda aquecida que poderá reverter em indicadores econômicos bastante atrativos. Na análise de risco é definida a probabilidade através de função densidade e de distribuição.

Nas Tabelas 13, 14 e 15, tem-se os resultados obtidos através das simulações de Monte Carlo, desenvolvidas pelo Software ALEAXPRJ. Foram feitas 500 simulações para cada sistema, onde uma simulação corresponde a um possível cenário.

Os resultados dos indicadores econômicos obtidos na análise de risco reforçam os resultados da análise determinista, demonstrando que a produção de rosas de corte a campo é mais atrativa sob ponto de vista econômico. As médias das taxas internas de retorno (TIR) são 54,007 e 50,172, para os sistemas de campo e estufa, respectivamente. Porém, o risco associado a este indicador para o sistema de campo é maior, pois o coeficiente de variação é quase que o dobro do sistema de estufa, provavelmente, por ser conduzido a céu aberto, sem a proteção de plásticos. Este maior risco também pode ser evidenciado pela distribuição de probabilidade da taxa interna de retorno (TIR) representados na Figura 2. Nesta mesma figura é possível verificar que o projeto de produção de rosas a campo pode apresentar as mesmas taxas internas de retorno que o projeto de produção de rosas em estufa, porém, com valores médios maiores.

O maior coeficiente de variação (CV), variável que mede o risco de determinado índice, é obtido para o valor atual (VA), do sistema de campo. Na média dos sistemas de produção de rosas, o menor coeficiente de variação é do custo total atualizado (CTA). Isto sugere que a maior parcela do risco está associada à receita e não aos custos. 
Tabela 13. Resultados das simulações do programa ALEAXPRJ, para o sistema de produção de rosas em campo, da variedade Vegas, no Município de Holambra.

\begin{tabular}{lrrrrr}
\hline Indicadores & Média & $\begin{array}{r}\text { Desvio } \\
\text { padrão }\end{array}$ & $\begin{array}{r}\text { CV } \\
(\%)\end{array}$ & Limite (L) & $\begin{array}{r}\text { P(I) } \\
(\%)\end{array}$ \\
\hline Taxa interna de retorno (TIR) - \% a. a. & 54,007 & 5,719 & 12,28 & 10,20 & 100,00 \\
Relação benefício-custo (RBC) & 1,295 & 0,049 & 3,78 & 1,00 & 100,00 \\
Valor atualizado (VA) - R $\$$ & $50.530,60$ & $9.159,76$ & 18,13 & $250.000,00$ & 0,00 \\
Custo total atualizado (CTA) - R $\$$ & $171.164,58$ & $2.969,55$ & 1,73 & $250.000,00$ & 0,00 \\
Payback Simples (PBS) - anos & 2,303 & 0,326 & 14,14 & 6,00 & 0,00 \\
Payback econômico (PBE) - anos & 2,512 & 0,245 & 9,77 & 6,00 & 0,00 \\
Custo unitário atualizado (CUA) - R\$/dz & 1,333 & 0,043 & 3,23 & 1,30 & 76,40 \\
\hline
\end{tabular}

Nota: A letra (L) indica um valor limite, definido arbitrariamente, para o respectivo i indicador econômico. Assim, $\mathrm{P}(\mathrm{I}>\mathrm{L})$ é a probabilidade do indicador apresentar valores superiores aos limites definidos. Os valores em reais $(R \$)$ correspondem ao período de outubro de 2002 .

O período de recuperação do capital, obtido pelo payback simples e econômico, apresenta diferenças entre os projetos na análise de risco. O projeto que apresenta maior payback é o sistema de campo, embora na análise determinista os valores não apresentem diferenças. Desta forma, o projeto que estará mais sujeito à incerteza é a produção de rosas a campo, porém, a proporção do seu payback em relação à vida útil do projeto é menor, o que diminui o risco de prejuízos.

Como a média do custo total atualizado para o sistema de produção a campo aumentou na análise de risco e o valor atual diminuiu em relação à análise determinista, a relação benefício-custo também diminui, obtendo-se o valor de 1,295 , enquanto que a relação benefício-custo do sistema de produção em estufa é de 1,304. Este aumento ou diminuição dos índices econômicos, em relação à análise determinista, deve-se à aleatoriedade dos fatores que compõe o fluxo de caixa. 


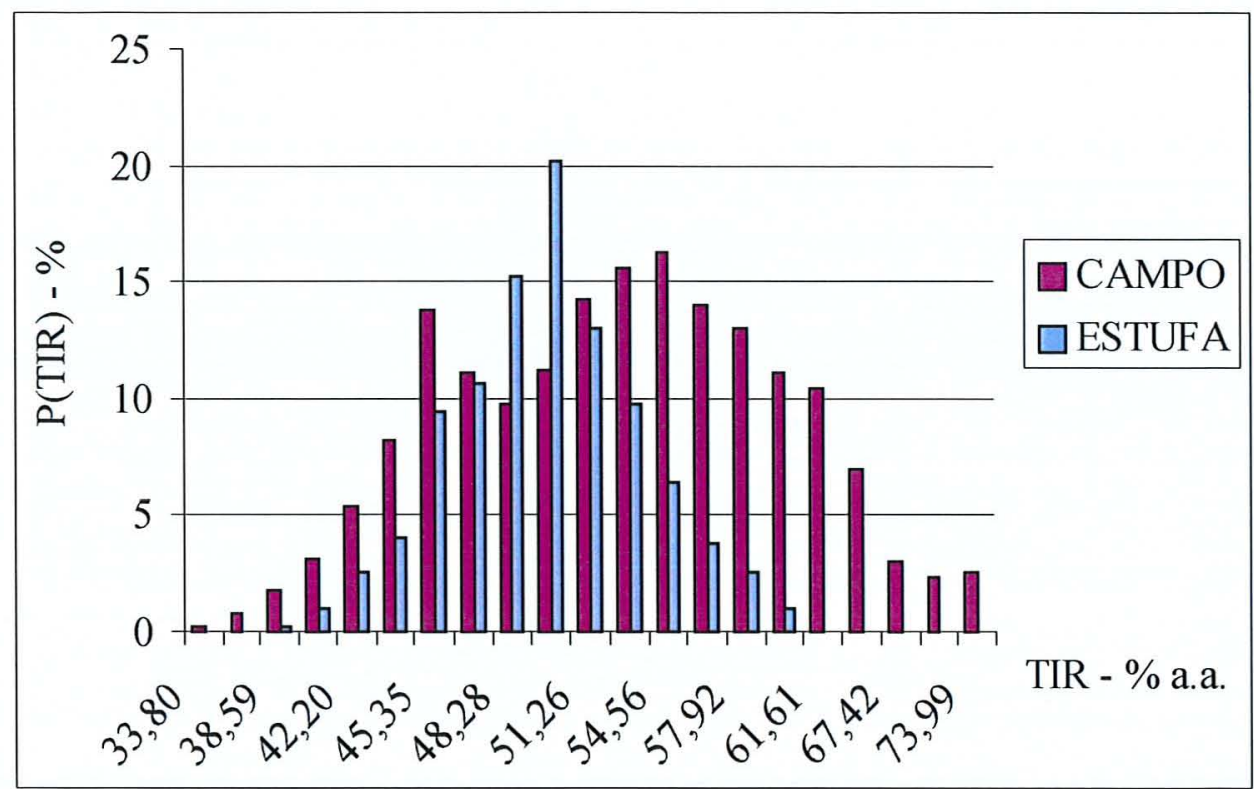

Figura 2 - Distribuição de probabilidade da taxa interna de retorno (TIR), para a produção de rosas, da variedade Vegas, nos sistemas de campo e estufa, Município de Holambra.

Nota: O P(I) é a probabilidade de ocorrência do indicador.

Da mesma forma que na análise determinista, foram calculados os indicadores econômicos para o projeto de produção de rosas em estufa considerando o custo de colheita e pós-colheita de produção de rosas a campo. Através destas simulações foram obtidos os resultados expostos na Tabela 15. Comparando estes resultados aos do sistema de campo, os índices econômicos são favoráveis à produção em estufa; isto porque, a taxa interna de retorno, o valor atual, a relação benefício-custo são maiores para o projeto de estufa, mesmo considerando maior o custo unitário atualizado de uma dúzia de rosas produzidas em estufa. 
Tabela 14. Resultados das simulações do programa ALEAXPRJ, para o sistema de produção de rosas em estufa, da variedade Vegas, no Município de Holambra.

\begin{tabular}{lrrrrr}
\hline & Média & \multicolumn{1}{c}{$\begin{array}{c}\text { Desvio } \\
\text { padrão }\end{array}$} & $\begin{array}{r}\text { CV } \\
(\%)\end{array}$ & Limite (L) & $\begin{array}{c}\text { P(I }>\mathrm{L}) \\
\text { Indicadores }\end{array}$ \\
\hline Taxa interna de retorno (TIR) - \% a. a. & 50,172 & 2,829 & 6,54 & 10,20 & 100,00 \\
Relação benefício-custo (RBC) & 1,304 & 0,028 & 2,15 & 1,00 & 100,00 \\
Valor atualizado (VA) - R $\$$ & $132.284,22$ & $12.531,72$ & 9,47 & $250.000,00$ & 0,00 \\
Custo total atualizado (CTA) - R\$ & $435.555,12$ & $3.514,85$ & 0,81 & $250.000,00$ & 100,00 \\
Payback Simples (PBS) - anos & 2,247 & 0,285 & 12,69 & 4,00 & 0,00 \\
Payback econômico (PBE) - anos & 2,492 & 0,128 & 5,13 & 4,00 & 0,00 \\
Custo unitário atualizado (CUA) - R $\$ / \mathrm{dz}$ & 2,271 & 0,019 & 0,84 & 2,50 & 0,00 \\
\hline
\end{tabular}

Nota: A letra (L) indica um valor limite, definido arbitrariamente, para o respectivo indicador econômico. Assim, $\mathrm{P}(\mathrm{I}>\mathrm{L})$ é a probabilidade do indicador apresentar valores superiores aos limites definidos. Os valores em reais $(R \$)$ correspondem ao período de outubro de 2002.

A comparação entre os coeficientes de variação, ou seja, do risco de cada indicador econômico, para cada alternativa de produção, encontra-se na Tabela 16. Nesta tabela, quando a relação for $100 \%$, significa que não há diferença entre os coeficientes de variação daquele indicador entre os projetos comparados. Desta forma, verifica-se que o coeficiente de variação da taxa interna de retorno (TIR) da alternativa de produção de rosas a campo apresenta $87,77 \%$ a mais de risco do que o coeficiente de variação do mesmo índice para a produção de rosas em estufa.

Tabela 15. Resultados das simulações do programa ALEAXPRJ, para o sistema de produção de rosas em estufa, com o custo em função da produção do sistema de campo aberto, da variedade Vegas, no Município de Holambra.

\begin{tabular}{|c|c|c|c|c|c|}
\hline Indicadores & Média & $\begin{array}{l}\text { Desvio } \\
\text { padrão }\end{array}$ & $\begin{array}{l}\mathrm{CV} \\
(\%)\end{array}$ & Limite (L) & $\begin{array}{c}\mathrm{P}(\mathrm{I}>\mathrm{L}) \\
(\%)\end{array}$ \\
\hline Taxa interna & 66,538 & 2,028 & 5,15 & 10,20 & 100,00 \\
\hline Rela & 1,489 & 0,032 & 2,15 & 1,00 & 100,00 \\
\hline & 94,46 & 96 & 6,79 & 00 & 0,00 \\
\hline Cus & 53 & 5,63 & 0,80 & 00,00 & 100,00 \\
\hline$P a y b$ & 1,751 & 0,12 & 6,85 & 4,00 & 0,00 \\
\hline Paybac & 1,977 & 0,238 & 12,06 & 4,00 & 0,00 \\
\hline Custo unitário atualizado (CUA) - $\mathrm{R} \$ / \mathrm{dz}$ & 1,986 & 0,019 & 0,96 & 2,5 & 0,00 \\
\hline
\end{tabular}

Nota: A letra (L) indica um valor limite, definido arbitrariamente, para o respectivo indicador econômico. Assim, $\mathrm{P}(\mathrm{I}>\mathrm{L})$ é a probabilidade do indicador apresentar valores superiores aos limites definidos. Os valores em reais (R\$) correspondem ao período de outubro de 2002. 
A maior diferença de risco está associado ao custo unitário atualizado (CUA), entre as alternativas de produção de rosas de corte a campo aberto e em estufa. O sistema considerado de produção de rosas, como o custo de colheita e pós-colheita do sistema de campo é o que apresenta menor risco associado aos seus indicadores econômicos, em compensação o sistema de produção a campo é o que apresenta maior risco (maiores coeficientes de variação).

Tabela 16. Relação entre os coeficientes de variação dos índices dos econômicos das alternativas de produção de rosas em campo aberto, em estufa e em estufa com os custos em função da produção do sistema de campo.

\begin{tabular}{lccc}
\hline \multirow{2}{*}{ Indicadores } & \multicolumn{3}{c}{ Coeficientes de variação } \\
\cline { 2 - 4 } & Campo/Estufa & Campo/Estufa* & Estufa/Estufa* \\
\hline Taxa interna de retorno (TIR) & 187,77 & 238,45 & 126,99 \\
Relação beneficio-custo (RBC) & 175,81 & 175,81 & 100,00 \\
Valor atualizado (VA) & 191,45 & 267,01 & 139,47 \\
Custo total atualizado (CTA) & 213,58 & 216,25 & 101,25 \\
Payback Simples (PBS) & 111,43 & 206,42 & 185,26 \\
Payback econômico (PBE) & 190,45 & 81,01 & 42,54 \\
Custo unitário atualizado (CUA) & 384,52 & 336,46 & 87,50 \\
\multicolumn{1}{r}{ Média } & 207,86 & 217,34 & 111,86 \\
\hline
\end{tabular}




\section{CONCLUSÕES}

Nas condições estabelecidas para os dois sistemas de produção, pode-se inferir que os dois sistemas de produção de rosa são viáveis economicamente, tanto em situações deterministas como em condições de risco. Neste particular, a análise de risco é a que mais se aproxima das condições do mundo real revelando que é praticamente nula a probabilidade dos projetos apresentarem prejuízos.

O produto que apresenta maior valor de mercado é a rosa produzida em estufa, cujos preços médios da dúzia (a valores de outubro de 2002) é de $\mathrm{R} \$ 2,71$ de melhor qualidade, e a produzida em campo aberto é de $\mathrm{R} \$ 1,63$. O risco associado ao preço é $33 \%$ maior para as rosas produzidas a campo. O custo unitário de produção para os sistemas de estufa e de campo é de $R$ \$2,31/dúzia e $R \$ 1,31 /$ dúzia, respectivamente (valores de outubro de 2002).

Mesmo com valores de vendas e produtividade mais altas, o sistema de produção de rosas de corte em estufa apresenta indicadores de rentabilidade inferiores aos obtidos para o sistema de produção em campo. A sua demanda de capital por área, detectada pelo custo total atualizado (CTA) é maior, devido aos investimentos iniciais mais elevados -e agravada pela estimativa de menor vida econômica útil. O valor atual (VA) do sistema de produção de rosas em estufa também é maior, mas não o suficiente para tornar a relação benefício-custo favorável à produção de rosas em estufa.

Caso se utilize os custos de colheita e pós-colheita vigentes na produção de rosas a campo aberto no sistema de produção de estufa, a preferência se inverte, ou seja, seria preferivel produzir rosas em estufa da variedade Vegas. Provavelmente, a produção de 
rosas em estufa se mostraria mais atrativa economicamente, se fossem utilizados os preços de comercialização dos próprios produtores estudados, e não coletados no Veiling.

Variando os custos de oportunidade do capital (a taxas de juros de 10,2\%, 20\% e $30 \%$ ao ano), os resultados na ótica mostram que o sistema de produção de rosas em campo é a melhor alternativa, observadas as condições estabelecidas no modelo.

As remunerações do capital durante a vida útil dos projetos, medidas pelas taxas internas de retorno (TIR), apresentaram coeficientes superiores para a produção de rosas de corte em campo. O risco associado a este índice é $87,77 \%$ maior para o sistema de produção de rosas a campo do que para o sistema de produção em estufa. Existe, porém, a possibilidade de ambos os projetos apresentarem a mesma taxa interna de retorno.

Para os dois casos de produção de rosas estudados, o indicador de menor risco está associado ao custo total atualizado (CTA) seguido pelo custo unitário atualizado (CUA). Em contrapartida, os índices de maiores riscos são: o valor atual (VA) e o payback simples (PBS). Entre os projetos, o que apresentou indicadores econômicos a riscos maiores foi a alternativa de produção de rosas a campo.

A rentabilidade econômica dos projetos são mais sensiveis à variação dos componentes de receita, quantidade comercializada e preço, em especial às variações de preços. Alguns indicadores econômicos variam mais de um porcento com a variação de um porcento no preço ou quantidade comercializada. Já para os custos de produção, esta elasticidade é menor que um, mostrando-se mais sensível às oscilações do custo de implantação de estrutura fixa, seguido pelos custos operacionais.

De forma geral, nas condições estabelecidas, os indicadores de rentabilidade mostram atratividade aos investimentos exigidos pelos sistemas. Porém, devem ser interpretados com cautela, pois são aproximações de estudos de casos, face aos 
diferentes sistemas de produção detectados nas visitas e entrevistas efetuadas com os produtores de rosas em Holambra.

Uma limitação do trabalho está associado ao caráter de se tratar de estudo de casos, perdendo representatividade de inúmeros sistemas de produção, praticados em Holambra. Embora seja um bom indicativo sobre a melhor alternativa de produção de rosas de corte, não pode ser considerado conclusivo na indicação da melhor técnica de produção. Na floricultura, dado as suas peculiaridades e especificações, mais presente que em outras explorações é comum entender que "cada cabeça uma sentença", ou seja, "cada produtor um sistema de produção" e "cada sistema de produção, um custo de produção diferente".

Outra limitação é o horizonte temporal dos dados disponíveis, por se tratar de um período muito curto, pois representam apenas dois anos. Estes não abrangem, para ambos sistemas estudados, um ciclo completo da cultura.

Para outras pesquisas sugere-se a incorporação de riscos associados a fatores acidentais (clima, ventos fortes, chuva de granizo, geadas, etc.) e outros considerando intermediação de compra e venda do produto (honra de contratos entre produtores e agentes de comercialização na intermediação dos produtos), maior extensão no horizonte temporal, principalmente no que refere aos preços de mercado e as quantidades comercializadas. 
ANEXOS 
ANEXO A - Preços e quantidades comercializadas de rosas de corte da variedade Vegas, segundo o sistema de produção.

Tabela 17. Médias e desvios-padrão das quantidades mensais vendidas por hectare e os respectivos preços médios e seus desvios-padrão por dúzia comercializada (Veiling Holambra), de acordo com o sistema de produção adotado.

\begin{tabular}{ccccccccc}
\hline & \multicolumn{3}{c}{ SISTEMA DE ESTUFA } & \multicolumn{3}{c}{ SISTEMA DE CAMPO } \\
\cline { 2 - 8 } MÊS & PRODUTIVIDADE & \multicolumn{2}{c}{ PREÇO } & PRODUTIVIDADE & \multicolumn{2}{c}{ PREÇO } \\
\cline { 2 - 8 } & MÉDIA & $\sigma^{2}$ & MEDIO & $\sigma^{2}$ & MÉDIA & $\sigma^{2}$ & MEDIO & $\sigma^{2}$ \\
\hline Jan. & 4.282 & 362 & 1,44 & 0,25 & 1.626 & 1.292 & 0,79 & 0,04 \\
Fev. & 9.123 & 773 & 1,80 & 0,26 & 1.505 & 1.466 & 0,89 & 0,26 \\
Mar. & 6.947 & 206 & 2,21 & 0,33 & 2.813 & 1.595 & 1,17 & 0,24 \\
Abr. & 8.553 & 338 & 2,39 & 0,50 & 1.905 & 1.386 & 1,44 & 0,36 \\
Maio & 7.365 & 592 & 4,15 & 0,33 & 5.012 & 1.973 & 2,92 & 0,43 \\
Jun. & 5.453 & 167 & 4,40 & 0,62 & 3.656 & 269 & 2,87 & 0,16 \\
Jul. & 4.047 & 185 & 3,16 & 0,81 & 3.008 & 231 & 1,93 & 0,61 \\
Agosto & 2.865 & 251 & 3,23 & 0,75 & 2.090 & 102 & 1,85 & 0,35 \\
Set. & 6.012 & 508 & 3,32 & 1,65 & 3.793 & 1.814 & 2,21 & 1,18 \\
Out. & 5.118 & 333 & 1,57 & 0,59 & 3.029 & 1.275 & 0,87 & 0,08 \\
Nov. & 5.853 & 54 & 1,96 & 1,02 & 3.869 & 538 & 0,87 & 0,06 \\
Dez. & 6.888 & 329 & 2,31 & 0,57 & 3.234 & 729 & 1,24 & 0,33 \\
\hline Nat. Qunyyyyyy
\end{tabular}

Nota: Quantidades expressas em dúzias e, preços em $\mathrm{R} \$ / \mathrm{dz}$ (out. 2002) pagos aos produtores de rosa de corte da variedade Vegas.

Tabela 18. Preços trimestrais mínimos, médios e máximos, de rosas de corte da variedade Vegas, comercializada no Veiling-Holambra.

\begin{tabular}{lcccccc}
\hline & \multicolumn{3}{c}{ Estufa } & \multicolumn{3}{c}{ Campo } \\
\cline { 2 - 7 } PERÍODO & Mínimo & Médio & Máximo & Mínimo & Médio & Máximo \\
\hline Janeiro a março & 1,57 & 1,82 & 2,10 & 0,77 & 0,95 & 1,13 \\
Abril a junho & 3,16 & 3,65 & 4,13 & 2,09 & 2,41 & 2,73 \\
Julho a setembro & 2,17 & 3,24 & 4,31 & 1,28 & 2,00 & 2,71 \\
Outubro a dezembro & 1,22 & 1,95 & 2,67 & 0,84 & 0,99 & 1,15 \\
\hline
\end{tabular}

Nota: Valores em reais por dúzia (out. 2002) 
Tabela 19. Produções mínimas, mais prováveis e máximas, para 1 ciclo de produção da rosa de corte da variedade Vegas, nos sistema de estufa, no Município de Holambra-SP.

\begin{tabular}{crrrcccc}
\hline & \multicolumn{1}{c}{ Mais } & & & & Mais \\
Mês & Mínimo & provável & Máximo & Mês & Mínimo & provável & Máximo \\
\hline 4 & 0,00 & 181,00 & 362,00 & 27 & $6.559,33$ & $6.888,92$ & $7.217,58$ \\
5 & 253,34 & $1.026,34$ & $1.799,34$ & 28 & $3.920,15$ & $4.282,35$ & $4.644,38$ \\
6 & $1.357,07$ & $1.563,07$ & $1.769,07$ & 29 & $8.350,78$ & $9.123,44$ & $9.896,83$ \\
7 & $2.548,64$ & $2.886,64$ & $3.224,64$ & 30 & $6.741,43$ & $6.947,21$ & $7.153,08$ \\
8 & $2.722,25$ & $3.314,25$ & $3.906,25$ & 31 & $8.215,89$ & $8.553,29$ & $8.891,17$ \\
9 & $2.900,31$ & $3.067,31$ & $3.234,31$ & 32 & $6.773,05$ & $7.365,67$ & $7.957,44$ \\
10 & $2.546,72$ & $2.731,72$ & $2.916,72$ & 33 & $5.286,41$ & $5.453,18$ & $6.520,41$ \\
11 & $2.005,19$ & $2.258,19$ & $2.507,19$ & 34 & $3.862,52$ & $4.047,56$ & $4.232,23$ \\
12 & $4.902,80$ & $5.410,80$ & $5.918,80$ & 35 & $2.614,46$ & $2.865,34$ & $3.116,88$ \\
13 & $4.315,83$ & $4.648,83$ & $4.981,83$ & 36 & $5.504,48$ & $6.012,98$ & $6.520,87$ \\
14 & $5.311,21$ & $5.365,21$ & $5.419,21$ & 37 & $4.742,35$ & $5.075,35$ & $5.408,35$ \\
15 & $6.042,33$ & $6.371,33$ & $6.700,33$ & 38 & $5.701,45$ & $5.755,45$ & $5.809,45$ \\
16 & $3.634,48$ & $3.996,48$ & $4.358,47$ & 39 & $6.386,80$ & $6.715,80$ & $7.044,80$ \\
17 & $7.817,67$ & $8.590,67$ & $9.363,67$ & 40 & $3.777,27$ & $4.139,27$ & $4.501,27$ \\
18 & $6.393,51$ & $6.599,51$ & $6.805,51$ & 41 & $7.969,88$ & $8.742,89$ & $9.515,88$ \\
19 & $7.858,42$ & $8.196,42$ & $8.534,42$ & 42 & $6.393,65$ & $6.599,65$ & $6.805,65$ \\
20 & $6.527,30$ & $7.119,30$ & $7.711,30$ & 43 & $7.716,08$ & $8.054,08$ & $8.392,08$ \\
21 & $5.149,51$ & $5.316,51$ & $5.483,51$ & 44 & $6.282,00$ & $6.874,00$ & $7.466,00$ \\
22 & $3.794,41$ & $3.979,41$ & $4.164,41$ & 45 & $4.877,03$ & $5.044,03$ & $5.211,03$ \\
23 & $2.590,02$ & $2.841,02$ & $3.092,02$ & 46 & $3.524,75$ & $3.709,75$ & $3.894,75$ \\
24 & $5.503,76$ & $6.011,76$ & $6.519,76$ & 47 & $2.351,37$ & $2.602,38$ & $2.853,38$ \\
25 & $4.785,42$ & $5.118,65$ & $5.451,14$ & 48 & $4.902,80$ & $5.410,80$ & $5.918,80$ \\
26 & $5.799,87$ & $5.853,28$ & $5.907,77$ & - & - & - & - \\
\hline
\end{tabular}

Nota: Produção dada em dúzias por hectare, com expectativa de ciclo de 4 anos para 0 roseiral. 
Tabela 20. Produções mínimas, mais prováveis e máximas para um ciclo de produção da rosa de corte da variedade Vegas, no sistema de campo aberto, no Município de Holambra-SP.

\begin{tabular}{|c|c|c|c|c|c|c|c|}
\hline \multicolumn{5}{|c|}{ Mais } & \multicolumn{3}{|c|}{ Mais } \\
\hline Mês & Mínimo & provável & Máximo & Mês & Mínimo & provável & Máximo \\
\hline 6 & 0,00 & $7.97,50$ & $1.595,65$ & 40 & 280,95 & $1.571,80$ & $2.864,20$ \\
\hline 7 & 0,00 & $.85,75$ & $1.672,48$ & 41 & 0,72 & $1.442,29$ & $2.908,32$ \\
\hline 8 & 0,00 & $1.503,60$ & $3.477,58$ & 42 & $1.077,77$ & $2.672,36$ & $4.267,16$ \\
\hline 9 & $1.376,14$ & $1.645,20$ & $1.914,20$ & 43 & 408,14 & $1.793,88$ & $3.180,20$ \\
\hline 10 & $1.574,35$ & $1.804,83$ & $2.036,34$ & 44 & $2.705,36$ & $4.677,88$ & $6.651,35$ \\
\hline 11 & $1.466,79$ & $1.567,51$ & $1.670,05$ & 45 & $3.113,70$ & $3.381,81$ & $3.651,45$ \\
\hline 12 & $1.600,85$ & $3.413,72$ & $5.228,92$ & 46 & $2.526,28$ & $2.757,34$ & $2.988,80$ \\
\hline 13 & $1.476,52$ & $2.751,34$ & $4.026,37$ & 47 & $1.796,26$ & $1.898,42$ & $2.000,27$ \\
\hline 14 & $3.009,35$ & $3.546,58$ & $4.085,26$ & 48 & $1.600,85$ & $3.413,71$ & $5.228,87$ \\
\hline 15 & $2.262,22$ & $2.991,45$ & $3.720,46$ & 49 & $1.428,20$ & $2.703,39$ & $3.978,65$ \\
\hline 16 & 226,21 & $1.517,66$ & $2.810,55$ & 50 & $2.886,10$ & $3.424,08$ & 62,07 \\
\hline 17 & 0,00 & $1.417,21$ & 2.8 & 51 & 2.10 & $2.837,85$ & 7,02 \\
\hline 18 & $1.077,55$ & $2.672,35$ & 4.26 & 52 & 123,67 & $1.414,63$ & 7,00 \\
\hline 19 & 440,46 & $1.825,62$ & $3.212,67$ & 53 & 0,00 & $1.298,07$ & $2.764,75$ \\
\hline 20 & $2.872,75$ & $4.844,93$ & $6.818,59$ & 54 & 810,12 & $2.405,13$ & $4.000,37$ \\
\hline 21 & $3.296,48$ & $3.564,68$ & $3.834,45$ & 55 & 228,18 & $1.614,49$ & $3.000,80$ \\
\hline 22 & $2.727,62$ & $2.957,87$ & 3.18 & 56 & $2.237,34$ & $4.210,10$ & 33,48 \\
\hline 23 &, 32 & $2.072,58$ & 2.1 & 57 & 2.77 & $3.043,63$ & ,35 \\
\hline 24 & $1.979,52$ & $3.793,15$ & $5.607,21$ & 58 & $2.251,75$ & $2.481,61$ & 3,63 \\
\hline 25 & $1.754,48$ & $3.029,23$ & $4.304,46$ & 59 & $1.607,07$ & $1.708,58$ & $1.811,86$ \\
\hline 26 & $2.231,76$ & $3.869,45$ & $4.407,38$ & 60 & $1.258,04$ & $3.072,34$ & $4.886,37$ \\
\hline 27 & $2.505,22$ & $3.234,55$ & $3.963,75$ & 61 & $1.156,63$ & $2.430,78$ & 06,77 \\
\hline 28 & 334,65 & $1.626,46$ & 2.91 & 62 & 2.53 & $3.075,87$ & 4,41 \\
\hline 29 & 39,22 & $1.505,28$ & $2.971,21$ & 63 & $1.818,71$ & $2.546,79$ &, 65 \\
\hline 30 & $1.218,35$ & $2.813,34$ & $4.408,38$ & 64 & 0,00 & $1.268,29$ & $2.560,68$ \\
\hline 31 & 519,48 & $1.905,85$ & $3.291,61$ & 65 & 0,00 & $1.162,62$ & $2.629,50$ \\
\hline 32 & $3.039,98$ & $5.012,46$ & $6.985,53$ & 66 & 557,69 & $2.151,96$ & $3.747,67$ \\
\hline 33 & $3.387,87$ & $3.656,11$ & $3.925,18$ & 67 & 57,39 & $1.443,04$ & $2.829,21$ \\
\hline 34 & $2.777,52$ & $3.008,64$ & $3.239,28$ & 68 & $1.786,32$ & $3.759,02$ & $5.732,17$ \\
\hline 35 & $1.988,36$ & $2.090,45$ & 2.19 & 69 & $2.446,21$ & $2.714,59$ & $2.984,08$ \\
\hline 36 & $1.979,25$ & $3.793,87$ & $5.607,78$ & 70 & $1.980,92$ & $2.210,89$ & $2.442,54$ \\
\hline 37 & $1.729,45$ & $3.003,76$ & $4.279,56$ & 71 & $1.418,33$ & $1.520,48$ & $1.622,36$ \\
\hline 38 & $3.267,85$ & $3.804,52$ & $4.343,68$ & 72 & 917,46 & $2.730,97$ & $4.545,47$ \\
\hline 39 & $2.424,35$ & $1.571,80$ & $3.882,39$ & - & - & . & - \\
\hline
\end{tabular}

Nota: Produção dada em dúzias por hectare, com ciclo da cultura de 6 anos. 
ANEXO B - Gastos numa área de um hectare de rosa de corte e prejuízos com a não comercialização de rosas, segundo o sistema de produção.

\section{Sistema de Produção em Estufa}

\subsection{Investimento em estrutura fixa}

Tabela 21. Gastos com materiais para a construção de um hectare de estufa de estrutura de madeira (eucalipto) visando a produção de rosas de corte.

\begin{tabular}{|c|c|c|c|c|}
\hline Discriminação & & Quantidade & Preço unitário & Valor Total (R\$) \\
\hline Pés direitos - $8 \times 8 \times 4,5 \mathrm{~m}$ & (unid.) & 644,00 & 11,25 & $7.245,00$ \\
\hline Tesouras - $8 \times 4 \times 4 m$ & (unid.) & $1.250,00$ & 4,80 & $6.000,00$ \\
\hline $6 \times 4 \times 3,5 \mathrm{~m}$ & (unid.) & 625,00 & 8,20 & $5.125,00$ \\
\hline Calhas $-20 \times 2,5 \times 5,0 \mathrm{~m}$ & (unid.) & 625,00 & 9,50 & $5.937,50$ \\
\hline Trava $-6 \times 4 \times 4 m$ & (unid.) & 272,00 & 4,40 & $1.196,80$ \\
\hline Travessas - $6 \times 4 \times 5 \mathrm{~m}$ & (unid.) & 625,00 & 5,50 & $3.437,50$ \\
\hline Ripas - 1m & (metros) & $9.901,30$ & 0,20 & $1.980,26$ \\
\hline Mourões - $15 \times 15 \times 1,5 \mathrm{~m}$ & (unid.) & 164,47 & 12,00 & $1.973,64$ \\
\hline Parafusos - 3/8" 7,5 " & (unid.) & 644,00 & 0,62 & 399,28 \\
\hline $5 / 16^{\prime \prime} \times 3,5 "$ & (unid.) & $1.875,00$ & 0,27 & 506,25 \\
\hline $5 / 16^{\prime \prime} \times 6,5 "$ & (unid.) & 921,05 & 0,45 & 414,47 \\
\hline Pregos - $17 \times 21$ & $(\mathrm{~kg})$ & 164,47 & 2,90 & 476,96 \\
\hline Esticadores & (unid.) & 88,81 & 1,53 & 135,87 \\
\hline Fio liso de cerca $-10 \mathrm{~mm}$ & (m) & 986,84 & 0,38 & 374,99 \\
\hline Plástico transp. $-150 \mu$ & Bobina & 8,22 & 760,00 & $6.247,20$ \\
\hline Plástico leitoso & Bobina & 8,22 & 935,00 & $7.685,70$ \\
\hline Sombrite - $40 \%$ & $\left(\mathrm{~m}^{2}\right)$ & $1.806,18$ & 1,25 & $2.257,72$ \\
\hline Tubo - $200 \mathrm{~mm}$ & $(\mathrm{~m})$ & 115,13 & 13,31 & $1.532,38$ \\
\hline Canal de concreto & (m) & 210,52 & 25,00 & $5.263,00$ \\
\hline Terraço & (m) & 210,52 & 5,00 & $1.052,60$ \\
\hline & & & Total & $59.242,14$ \\
\hline
\end{tabular}

Nota: Valores expressos em reais (R\$) de outubro de 2002.

Tabela 22. Custo para a construção de um hectare de estufa de estrutura de madeira, para o plantio de rosas de corte no Município de Holambra-SP.

\begin{tabular}{lr}
\hline Discriminação & Total \\
\hline Material & $59.242,14$ \\
Mão-de-obra & $11.000,00$ \\
& Total $70.242,14$ \\
\hline
\end{tabular}

Nota.: Valores expressos em reais de outubro de 2002. 
Tabela 23. Custos por hectare para a implantação de sistema de pulverização, no sistema de estufa.

\begin{tabular}{lccc}
\hline Discriminação & Quantidade & \multicolumn{2}{c}{ Preço unitário Valor total (R\$) } \\
\hline Casa de preparação de calda - 3,2×2,9m & 0,37 & 150,00 & 55,50 \\
Cx d’água de amianto - 10001 & 0,37 & 123,58 & 45,72 \\
Cx d’água tipo torre - 3000 1 & 0,37 & $6.000,00$ & $2.220,00$ \\
Bomba Jacto LAV - 500 c/ motor 6 CV & 0,37 & 1.350 & 499,50 \\
Tanque para calda - 1001 & 0,37 & 250 & 92,50 \\
Balança - capacidade de 5 kg & 0,37 & 25,95 & 9,60 \\
PVC rígido - 3/4" (m) & 105,26 & 2,57 & 270,52 \\
PVC rígido - 1/2" (m) & 3,29 & 2,02 & 6,65 \\
Registro Tipo Esfera - 1/2" & 6,58 & 12,28 & 80,80 \\
Mangueira de pulverização (m) & 125,00 & 4,74 & 592,5 \\
Barra de pulverizar c/ 3 bicos & 1,20 & 34,54 & 41,45 \\
Pulverizador costal jacto - 20 1 & 0,50 & 32,97 & 16,49 \\
Mão-de-obra para instalação do sistema & - & - & 500,00 \\
& & Total & $4.431,23$ \\
\hline
\end{tabular}

Nota: Valores expressos em reais de outubro de 2002.

Tabela 24. Custos de implantação de sistema de irrigação em um hectare de estufa de rosa.

\begin{tabular}{lccr}
\hline \multicolumn{1}{c}{ Discriminação } & Quantidade & Preço unitário & Valor total (R\$) \\
\hline Mangueira preta 3/4" - PN 30 (m) & $7.812,50$ & 0,80 & $6.250,00$ \\
Microaspersor & $7.812,50$ & 0,50 & $3.906,25$ \\
Tubulação 50 mm - (m) & 328,94 & 2,26 & 743,40 \\
Registro automatico & 8,22 & 531,02 & $4.364,98$ \\
Fiação elétrica - 1,5mm (m) & 822,36 & 0,26 & 213,81 \\
Conduite 3/4" - tigre (m) & 411,18 & 0,28 & 115,13 \\
Sist. de bomba 15CV e 600001/h & 0,37 & $2.552,00$ & 944,24 \\
Caixa d água para adubo & 0,37 & 123,58 & 45,72 \\
Casa de bomba & 0,37 & $1.350,00$ & 499,5 \\
Mão-de-obra & - & - & 500,00 \\
& & & Total \\
\hline
\end{tabular}

Nota: Valores expressos em reais de outubro de 2002. 
Tabela 25. Investimento em estrutura de colheita, para um hectare de rosas de corte, em estufa.

\begin{tabular}{lccc}
\hline Discriminação & Quantidade & Preço unitário & Valor total \\
\hline Tubo (3/4") (m) & 115,13 & 2,57 & 295,88 \\
Registro tipo esfera 3/4" & 6,58 & 15,60 & 102,64 \\
Cx d'água de plástico (500 1) & 3,29 & 98,86 & 325,25 \\
Bancada de madeira & 3,29 & 50,00 & 164,50 \\
Carrinho de colheita & 3,29 & 100,00 & 329,00 \\
Mão-de-obra & - & - & 200,00 \\
& & & Total \\
\hline
\end{tabular}

Nota: Valores expressos em reais de outubro de 2002.

Tabela 26. Investimento em estrutura de pós-colheita para um hectare de produção de rosas de corte.

\begin{tabular}{lccc}
\hline Discriminação & Quantidade & Preço unitário & Valor Total (R\$) \\
\hline Desenho da embalagem & 1,00 & 300,00 & 300,00 \\
Galpão & 61,00 & 150,00 & $9.150,00$ \\
Câmara fria & 3,00 & 950,00 & $2.850,00$ \\
Mesa de classificação & 1,48 & 600,00 & 888,00 \\
Mesa de Embalar & 2,56 & 200,00 & 512,00 \\
Guilhotina & 0,37 & 500,00 & 185,00 \\
Desfolhadora & 0,37 & $1.200,00$ & 444,00 \\
& & & Total $14.329,00$ \\
\hline
\end{tabular}

Nota: Valores expressos em reais de outubro de 2002.

Tabela 27. Investimento em transformador de energia, necessários para conduzir um hectare de lavoura de rosas de corte.

\begin{tabular}{lccc}
\hline Discriminação & Quantidade & Preço unitário & Valor Total (R\$) \\
\hline Transformador de 45 kva & 0,37 & $4.500,00$ & $1.665,00$ \\
& & Total & $1.665,00$ \\
\hline
\end{tabular}

Nota: Valores expressos em reais de outubro de 2002. 
Tabela 28. Total de investimento em estrutura fixa para produzir rosas de corte em um hectare, no sistema de estufa.

\begin{tabular}{|c|c|}
\hline Discriminação & Valor total (R\$) \\
\hline Construção da estufa & $70.242,14$ \\
\hline Sistema de pulverização & $4.431,23$ \\
\hline Sistema de irrigação localizada & $17.583,05$ \\
\hline Estrutura de colheita & $1.417,25$ \\
\hline Estrutura de pós-colheita & $14.329,00$ \\
\hline \multirow[t]{2}{*}{ Transformador } & $1.665,00$ \\
\hline & $109.667,67$ \\
\hline
\end{tabular}

Nota: Valores expressos em reais de outubro de 2002.

1.2 Custo para a troca de plástico para estufas destinadas à produção de rosas de corte, em uma área de um hectare, no Município de Holambra-SP

Tabela 29. Gastos necessários para a troca de plásticos em 1 (um) hectare de estufa de estrutura de madeira.

\begin{tabular}{|c|c|c|c|}
\hline Discriminação & Quantidade & Preço unitário & Valor Total \\
\hline Pregos $(17 \times 21)$ & 164,47 & 2,90 & 476,96 \\
\hline Ripas (1m) & $9.901,30$ & 0,20 & $1.980,26$ \\
\hline Plásticos transparente & 8,22 & 760,00 & $6.247,20$ \\
\hline Plástico leitoso & 8,22 & 935,00 & $7.685,70$ \\
\hline \multirow[t]{2}{*}{ Mão-de-obra } & 32,89 & 100,00 & $3.289,00$ \\
\hline & & & $19.679,12$ \\
\hline
\end{tabular}

Nota: Valores expressos em reais de outubro de 2002.

\subsection{Custo da terra ou custo de oportunidade do capital investido em terreno com rosas de corte, no Município de Holambra-SP}

Tabela 30. Custo semestral por hectare da remuneração da terra, no município de Holambra-SP.

\begin{tabular}{lc}
\hline Discriminação & Valor Total \\
\hline Terreno & 150,00 \\
& Total \\
150,00
\end{tabular}

Nota: Valores expressos em reais de outubro de 2002. 


\subsection{Custos com manutenção e custos administrativos correspondentes a um hectare, no Município de Holambra-SP}

Tabela 31. Custos semestrais com manutenção para um hectare de produção de rosas de corte, no sistema de estufa, no Município de Holambra-SP.

\begin{tabular}{lc}
\hline Discriminação & Valor total (R\$) \\
\hline Sistema de pulverização & 90,00 \\
Sistema de irrigação & 350,00 \\
Sistema de colheita & 200,00 \\
Sistema de pós-colheita & 500,00 \\
& Total $1.140,00$ \\
\hline
\end{tabular}

Nota: Valores expressos em reais de outubro de 2002.

Tabela 32. Custos com manutenção e administrativos, num semestre, para um hectare de produção de rosas em estufa.

\begin{tabular}{lcc}
\hline Discriminação & & Valor Total (R\$) \\
\hline Custos semestrais com manutenção & $1.140,00$ \\
Custos semestrais com despesas administrativas & & 500,00 \\
& Total & $1.790,00$ \\
\hline
\end{tabular}

Nota: Valores expressos em reais de outubro de 2002.

\subsection{Gastos com o preparo do solo e implantação de um hectare de roseiral, no} sistema de estufa, Município de Holambra-SP

Tabela 33. Custo de preparo do solo e implantação de um hectare de rosas de corte, no Município de Holambra-SP.

\begin{tabular}{lrrr}
\hline & \multicolumn{3}{c}{ Valores } \\
\cline { 2 - 4 } Discriminação & Mínimo & Mais Provável & Máximo \\
\hline Correção & 157,88 & 236,98 & 263,67 \\
Distribuição de composto org. & 509,40 & 695,86 & 851,04 \\
Subsolagem & 220,30 & 239,02 & 253,34 \\
Pá rotativa & 231,30 & 250,83 & 269,85 \\
Enxada Rotativa & 128,00 & 150,34 & 169,62 \\
Marcação e abertura dos sulcos & 106,60 & 127,40 & 149,50 \\
Instalação das mangueira de irrig. & 42,90 & 45,50 & 50,70 \\
Distrib. De MB - 4 e farinha de osso & 505,69 & 509,54 & 533,80 \\
Plantio & $13.625,83$ & $13.720,52$ & $13.833,39$ \\
Replantio & $1.365,04$ & $1.371,80$ & $1.383,11$ \\
& & $17.347,79$ & $17.758,02$ \\
\hline
\end{tabular}

Nota: Valores expressos em reais de outubro de 2002. 


\subsection{Custos para a condução da cultura}

Tabela 34. Custo operacional/semestre, no sistema de produção de rosas de corte em estufa, no Município de Holambra-SP.

\begin{tabular}{lrcr}
\hline & \multicolumn{3}{c}{ Valores } \\
\cline { 2 - 4 } Discriminação & Mínimo & Mais Provável & Máximo \\
\hline Dobra das plantas & 727,59 & 564,46 & 711,57 \\
Emenda & 320,70 & 404,12 & 513,16 \\
Desbrota & 962,09 & $1.154,56$ & $1.347,02$ \\
Capina manual & 342,06 & 359,22 & 393,43 \\
Amostragem de pragas & 294,84 & 311,69 & 328,54 \\
Lavagem das plantas & 95,98 & 116,30 & 131,06 \\
Pulverização & $5.000,96$ & $8.442,59$ & $11.632,27$ \\
Amostragem de solo & 20,20 & 22,80 & 25,40 \\
Adubação & $3.355,46$ & $3.355,46$ & $3.355,46$ \\
Irrigação & 42,71 & 125,49 & 210,39 \\
& & $14.856,70$ & $18.648,30$ \\
\hline
\end{tabular}

Nota: Valores expressos em reais de outubro de 2002.

1.7 Custos que variam segundo a produtividade da cultura (Colocação de redinhas, ajustamento de redinhas, colheita, pós-colheita e comercialização)

Tabela 35. Custos variáveis em função da produção do roseiral, para o sistema de produção de rosas de corte em estufa no Município de Holambra-SP.

\begin{tabular}{|c|c|c|c|c|}
\hline \multirow{2}{*}{\multicolumn{2}{|c|}{ Discriminação }} & \multicolumn{3}{|c|}{ Valores } \\
\hline & & Mínimo & Mais provável & Máximo \\
\hline Colocação de redinhas & & 26,01 & 26,68 & 27,18 \\
\hline Ajustamento de redinhas & & 3,22 & 3,35 & 3,51 \\
\hline Colheita & & 9,75 & 11,7 & 14,62 \\
\hline Pós-colheita & & 76,32 & 85,37 & 95,55 \\
\hline Comercialização (verão) & & 9,45 & 9,45 & 9,45 \\
\hline & Total & 124,75 & 136,55 & 150,31 \\
\hline
\end{tabular}

Nota: Valores expressos em reais de outubro de 2002, para cada carrinho tipo Veiling (225 dúzias de rosas, da variedade Vegas. É necessário ainda acrescentar 9,3\% sobre o valor de venda, para o custo de comercialização. 
1.8 Custos para a produção de um hectare de rosas de corte, da variedade Vegas, no sistema de estufa, Município de Holambra-SP

Tabela 36. Custos e investimentos totais para a produção em um hectare de rosas de corte, da variedade Vegas, no Município de Holambra.

\begin{tabular}{lcrc}
\hline Custos & Mínimo & Mais provável & Máximo \\
\hline Investimento em estrutura fixa & - & $109.667,67$ & - \\
Troca de plástico (a cada 2 anos) & - & $19.679,12$ & - \\
Custo do terreno (semestral) & - & 150,00 & - \\
Manutenção e administrativos (semestral) & - & $1.790,00$ & - \\
Implantação & $16.892,94$ & $17.347,79$ & $17.758,02$ \\
Condução da cultura (semestral) & $11.162,20$ & $14.856,70$ & $18.648,30$ \\
Função da produção (225 dúzias) & 124,75 & 136,55 & 150,31 \\
\hline
\end{tabular}

Nota: Os valores são expressos em reais de outubro de 2002.

1.9 Prejuízos sofridos com o envio do produto ao centro de comercialização e não comercializados

Tabela 37. Prejuízos trimestrais mínimos, mais prováveis e máximos de rosas enviadas ao centro de comercialização (Veiling) e que não foram vendidas, para o sistema de estufa.

\begin{tabular}{lccc}
\hline Períodos & Mínimo & Mais Provável & Máximo \\
\hline Outubro a março & 8,60 & 92,92 & 147,99 \\
Abril a setembro & 0,00 & 27,50 & 77,60 \\
\hline
\end{tabular}

Nota: Valores expressos em reais de outubro de 2002. 


\section{Sistema de Produção a Campo Aberto}

\subsection{Investimento em estrutura fixa}

Tabela 38. Sistema de irrigação por aspersão, utilizado na produção de um hectare de rosa de campo.

\begin{tabular}{|c|c|c|c|}
\hline Discriminação & Quantidade & Preço unitário & Valor total \\
\hline Aspersor - mod A $23210123 \times 23$ (unid) & 61,27 & 10,00 & 612,70 \\
\hline Tubo 2" - PVC rígido - tub. Secundária (m) & 735,29 & 2,26 & $1.661,76$ \\
\hline Tubo 1" - PVC rígido - altura p/ aspersor $(\mathrm{m})$ & 110,28 & 5,16 & 569,04 \\
\hline T c/ redução de 2" p/ 1" (unid) e adaptador & 61,27 & 3,98 & 243,85 \\
\hline T c/ redução de tub princ. $p / 2^{\prime \prime}$ (unid) & 5,44 & 18,10 & 98,46 \\
\hline Tubo 4" - PVC rígido - Tub. primária (m) & 135,00 & 8,61 & $1.162,35$ \\
\hline Cotovelos 4" (unid) & 3,00 & 85,05 & 255,15 \\
\hline Conj moto bomba $45 \mathrm{CV}$ e $60.0001 / \mathrm{h}$ & 0,10 & $4.300,00$ & 430,00 \\
\hline \multirow[t]{2}{*}{ Mão-de-obra } & - & - & 500,00 \\
\hline & & Total & $5.533,32$ \\
\hline
\end{tabular}

Nota: Valores expressos em reais de outubro de 2002.

Tabela 39. Custo de implantação de sistema fixo de pulverização em um hectare de produção de rosas em campo.

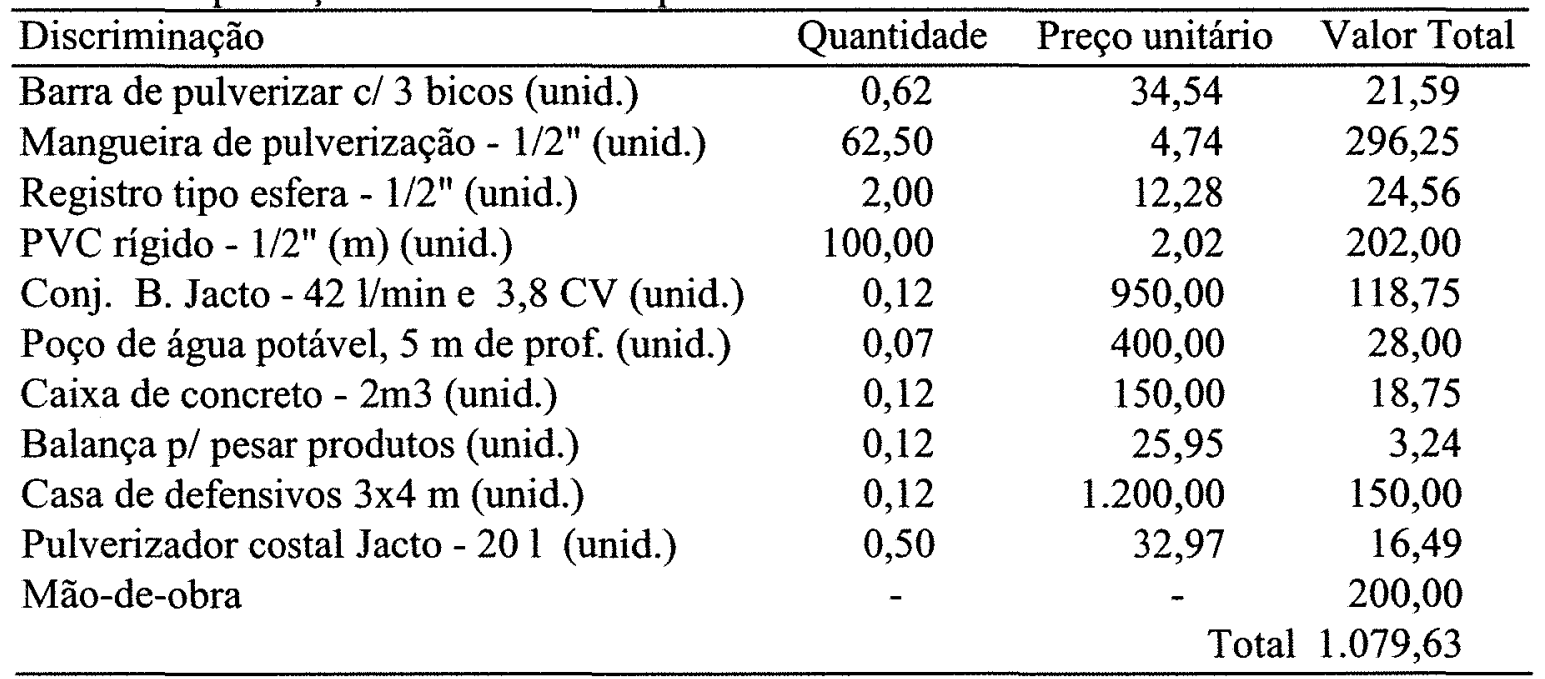

Nota: Valores expressos em reais de outubro de 2002. 
Tabela 40. Investimento demandado, em um hectare, para o sistema fixo de colheita da rosa produzida no campo.

\begin{tabular}{lccc}
\hline Discriminação & Quantidade & Preço unitário & Valor total \\
\hline Casa para proteção de flores $(1,5 \times 1,7 \mathrm{~m})$ & 2,00 & 50,00 & 100,00 \\
Registro tipo esfera - 1/2" & 2,00 & 12,28 & 24,56 \\
Cano PVC - 3/4" (m) & 100,00 & 2,57 & 257,00 \\
Mão-de-obra & - & - & 200,00 \\
& & Total & 581,56 \\
\hline
\end{tabular}

Nota: Valores expressos em reais de outubro de 2002.

Tabela 41. Investimentos necessários em estrutura fixa de pós-colheita para um hectare de rosa produzida no sistema de campo.

\begin{tabular}{lccr}
\hline Discriminação & Quantidade & Preço unitário & Valor total \\
\hline Desenho de embalagem & 1,00 & 300,00 & 300,00 \\
Galpão (m2) & 20,00 & 150,00 & $3.000,00$ \\
Mesas de classif. & 0,46 & 200,00 & 92,00 \\
Mesas de embalar & 0,60 & 800,00 & 480,00 \\
Grampeador & 0,26 & 8,00 & 2,08 \\
Guilhotina & 0,07 & 500,00 & 35,00 \\
Desfolhadeira & 0,07 & $1.200,00$ & 84,00 \\
Amarrador autom. & 0,07 & $14.000,00$ & 980,00 \\
Câmara fria (m2) & 2,00 & 900,00 & $1.800,00$ \\
& & & Total \\
\end{tabular}

Nota: Valores expressos em reais de outubro de 2002.

Tabela 42. Investimento em transformador de energia, necessários para conduzir um hectare de lavoura de rosas de corte.

\begin{tabular}{lccc}
\hline Discriminação & Quantidade & Preço unitário & Valor Total \\
\hline Transformador de 45 kva & 0,37 & $4.500,00$ & $1.665,00$ \\
& & Total & $1.665,00$ \\
\hline
\end{tabular}

Nota: Valores expressos em reais de outubro de 2002.

Tabela 43. Total de investimentos em estrutura fixa necessário para produzir em um hectare de rosas de campo.

\begin{tabular}{lc}
\hline Discriminação & Valor total $(\mathrm{R} \$)$ \\
\hline Sistema de irrigação & $5.033,32$ \\
Sistema de pulverização & $1.079,63$ \\
Estrutura de colheita & 581,56 \\
Estrutura de pós - colheita & $6.773,08$ \\
Transformador & $1.665,00$ \\
& Total $15.132,59$ \\
\hline
\end{tabular}

Nota: Valores expressos em reais de outubro de 2002. 
2.2 Custo da terra ou custo de oportunidade do capital investido em terreno com rosas de corte, no Município de Holambra-SP

Tabela 44. Custo semestral por hectare da remuneração da terra, no município de Holambra - SP.

\begin{tabular}{lc}
\hline Discriminação & Valor Total \\
\hline Terreno & 150,00 \\
& Total 150,00 \\
\hline
\end{tabular}

Nota: Valores expressos em reais de outubro de 2002.

\subsection{Custos com manutenção e custos administrativos correspondentes a um hectare, no Município de Holambra-SP}

Tabela 45. Custos semestrais com manutenção para um hectare de produção de rosas de corte, no sistema de campo, no Município de Holambra-SP.

\begin{tabular}{|c|c|}
\hline$\overline{\text { Discriminação }}$ & Valor (R\$) \\
\hline Sistema de pulverização & 60,00 \\
\hline Sistema de irrigação & 251,65 \\
\hline Sistema de colheita & 117,47 \\
\hline Sistema de pós - colheita & 202,76 \\
\hline & Total 631,88 \\
\hline
\end{tabular}

Nota: Valores expressos em reais de outubro de 2002.

Tabela 46. Custos com manutenção e administrativos, num semestre, para um hectare de produção de rosas em campo.

\begin{tabular}{|c|c|}
\hline Discriminação & Valor total $(\mathrm{R} \$)$ \\
\hline Custos semestrais com manutenção & 631,88 \\
\hline \multirow[t]{2}{*}{ Custos semestrais com despesas administrativas } & 500,00 \\
\hline & Total $1.131,88$ \\
\hline
\end{tabular}

Nota: Valores expressos em reais de outubro de 2002. 
2.3 Gastos com o preparo do solo e implantação de um hectare de roseiral, no sistema de campo aberto, Município de Holambra-SP

Tabela 47. Gastos, de um hectare, para o preparo do solo e implantação da cultura, no sistema de produção de rosas de corte produzidas em campo.

\begin{tabular}{lrrr}
\hline & \multicolumn{3}{c}{ Valores } \\
\cline { 2 - 4 } Discriminação & Mínimo & Mais Provável & Máximo \\
\hline Correção & 135,09 & 143,07 & 151,05 \\
Distribuição de composto orgânico & $1.255,36$ & $1.271,32$ & $1.287,28$ \\
Subsolagem & 77,10 & 88,12 & 99,13 \\
Aração & 88,44 & 110,55 & 132,66 \\
Gradagem & 53,74 & 60,45 & 67,17 \\
Sulcamento & 44,72 & 55,90 & 67,08 \\
Roçagem & 47,60 & 53,55 & 59,50 \\
Instalar sistema de irrigação & 10,40 & 11,70 & 13,00 \\
Adubação & 483,90 & 485,20 & 486,50 \\
Plantio & $8.218,02$ & 8224,52 & $9.231,02$ \\
Replantio & 821,80 & 822,45 & 923,10 \\
& $11.236,17$ & $11.326,83$ & $12.517,49$ \\
\hline
\end{tabular}

Nota: Valores expressos em reais de outubro de 2002. 


\subsection{Custos para a condução da cultura}

Tabela 48. Custos operacionais para um hectare da cultura da rosa de corte, no sistema de campo aberto.

\begin{tabular}{|c|c|c|c|c|}
\hline \multirow{2}{*}{\multicolumn{2}{|c|}{ Discriminação }} & \multicolumn{3}{|c|}{ Valores } \\
\hline & & Mínimo & Mais provável & Máximo \\
\hline \multicolumn{2}{|l|}{ Amostragem do solo } & 17,80 & 19,10 & 20,40 \\
\hline \multicolumn{2}{|l|}{ Capina Manual } & 375,33 & 421,67 & 468,00 \\
\hline \multicolumn{2}{|l|}{ Roçagem entre linha } & 142,80 & 166,60 & 190,28 \\
\hline \multicolumn{2}{|l|}{ Uso de herbicidas } & 362,40 & 372,80 & 383,20 \\
\hline \multicolumn{2}{|l|}{ Capina manual na linha } & 29,25 & 34,12 & 39,00 \\
\hline \multicolumn{2}{|l|}{ Pulverização } & $1.632,90$ & $1.696,00$ & $1.828,60$ \\
\hline \multicolumn{2}{|c|}{ Acompanhamento da irrigação } & 491,40 & 614,25 & 737,10 \\
\hline \multirow[t]{2}{*}{ Adubação em cobertura } & (orgânica) & $1.234,00$ & $1.247,00$ & $1.260,00$ \\
\hline & (química) & 171,20 & 175,10 & 218,00 \\
\hline \multicolumn{2}{|l|}{ Calcário } & 116,75 & 123,25 & 129,75 \\
\hline \multicolumn{2}{|l|}{ Emenda } & 238,94 & 286,04 & 327,71 \\
\hline \multicolumn{2}{|l|}{ Desbrota } & $1.030,20$ & $1.005,30$ & $1.611,10$ \\
\hline \multicolumn{2}{|l|}{ Monitoramento } & 176,90 & 186,70 & 169,56 \\
\hline \multicolumn{2}{|c|}{ Consumo de energia elétrica da irrigação } & 642,14 & 802,68 & 963,20 \\
\hline & Total & $6.662,00$ & $7.150,60$ & $8.345,90$ \\
\hline
\end{tabular}

Nota: Valores expressos em reais de outubro de 2002 . O uso de herbicidas, a roçagem na entre linha com capina na linha são prática adotadas a parti do terceiro semestre após a implantação da cultura. A adubação orgânica e a correção do solo são realizadas uma vez ao ano, durante o verão. A emenda das hastes e a desbrota das plantas iniciam no segundo semestre.

2.6 Custos que variam segundo a produtividade da cultura (colheita, pós-colheita e comercialização)

Tabela 49. Custo em função da produção de um carrinho tipo Veiling (225 dúzias), para o sistema de produção de rosas a campo.

\begin{tabular}{|c|c|c|c|c|}
\hline \multirow[b]{2}{*}{ Discriminação } & & \multicolumn{3}{|c|}{ Valores } \\
\hline & & Mínimo & Mais provável & Máximo \\
\hline Colheita & & 10,4 & 13,53 & 17,62 \\
\hline Pós-colheita & & 47,19 & 50,56 & 55,33 \\
\hline Comercialização & & 9,40 & 9,40 & 9,40 \\
\hline & Total & 66,99 & 73,49 & 82,35 \\
\hline
\end{tabular}

Nota: Valores expressos em reais de outubro de 2002, para cada carrinho tipo Veiling (225 dúzias de rosas, da variedade Vegas. É necessário ainda acrescentar 9,3\% sobre o valor de venda, para o custo de comercialização. 
2.7 Custos para a produção de um hectare de rosas de corte, da variedade Vegas, no sistema de campo aberto, Município de Holambra-SP

Tabela 50. Custos e investimentos totais para a produção em um hectare de rosas de corte, da variedade Vegas, no Município de Holambra.

\begin{tabular}{lrrr}
\hline Custos & Mínimo & Mais provável & Máximo \\
\hline Investimento em estrutura fixa & - & $15.132,59$ & - \\
Custo do terreno (semestral) & - & 150,00 & - \\
Manutenção e administrativos (semestral) & - & $1.131,88$ & - \\
Implantação & $11.236,17$ & $11.326,83$ & $12.517,49$ \\
Condução da cultura (semestral) & $6.662,00$ & $7.150,60$ & $8.345,90$ \\
Função da produção (225 dúzias) & 66,99 & 73,49 & 83,35 \\
\hline
\end{tabular}

Nota: Valores são expressos em reais de outubro de 2002.

2.8 Prejuízos sofridos com o envio do produto ao centro de comercialização e não comercializados

Tabela 51. Prejuízos trimestrais mínimos, mais prováveis e máximos de rosas enviadas ao centro de comercialização (Veiling) e que não foram vendidas, para o sistema de campo aberto.

\begin{tabular}{lccc}
\hline Períodos & Mínimo & Mais Provável & Máximo \\
\hline Outubro a março & 0,00 & 508,00 & $1.534,00$ \\
Abril a setembro & 0,00 & 145,00 & 841,00 \\
\hline
\end{tabular}

Nota: Valores expressos em reais de outubro de 2002. 


\section{REFERÊNCIAS BIBLIOGRÁFICAS}

ARAÚJO, M. da P. e MARQUES P.V. Rentabilidade, em condição de incerteza, na produção avícola sob contratos de integração vertical em Minas Gerais. Revista de Economia e Sociologia Rural, v.35, n.3, p.23-41, 1996.

ARRUDA, S.T; OLIVETTE, M.P. de A.; de CASTRO, C.E.F. Diagnóstico da floricultura do Estado de São Paulo. Revista Brasileira de Horticultura Ornamental, v.2, n.2, p.1-18, 1996.

AZEVEDO-FILHO, A.J. de B.V. Avaliação econômica de projetos: "Software" para simulações deterministas e de risco envolvendo simulações. Piracicaba, 1988. 127p. Dissertação (M.S.) - Escola Superior de Agricultura "Luiz de Queiroz", Universidade de São Paulo.

BANCO CENTRAL DO BRASIL. Informação econômica e financeira. http://www.bacen.org.br (10 nov. 2002)

BARLETTA, A. Stimulating demand for flowers in Brazil. Flora Culture International, v.5, n.9, p.38-39, Sep. 1995.

BEYTES, C. A systematic approach to production lines. Flora Culture International, v.5, n.12, p.10-11, Dec.1995. 
CASTRO, C.E.F. de Floricultura no Brasil. http://www. uesb.br/flower/florbrasil.html (10 jan. 2003)

CHABALIN, E. Análise econômica da criação de peixe sob condição de risco: um estudo de caso. Piracicaba, 1996. 62p. Dissertação (M.S.) - Escola Superior de Agricultura "Luiz de Queiroz", Universidade de São Paulo.

CORREA FILHO, J.; CONEJO, M. Primavera cearense. Panorama Rural: a revista do agronegócio, n.51, p.31-36, maio 2003.

EMOL. Economia y negocios. http:/Www.emol.com/diario_elmercurio/modulos/ buscar/_portada/detalle_diario.asp?idnoticia $=0113102001004 \mathrm{~d} 0050025 \quad(10$ oct. 2002)

FLORABRASILIS (compact disc). Campinas: IBRAFLOR/BRAZIL/APEX, 2002.

FLEISHER, G.A. Teoria da aplicação do capital: um estudo das decisões de investimento. São Paulo: Edgard Blücher, 1973. 272p.

FUNDAÇÃO INSTITUTO DE PESQUISA ECONOMICA Índices. http://www.fipe.com.br (10 nov. 2002)

HAMRICK, D. One dutch rose grower steps of the "more production is better" treadmill. Flora Culture International, v.5, n.10, p.22-23, Oct. 1995.

HOFFMANN, R.; SERRANO, O.; NEVES, E.M.; THAME A.C. de M.; ENGLER, J.J. de C. Administração da empresa agrícola. São Paulo: Pioneira, 1976. 323p. 
HUMMEL, P.R.V.; TASHNER, M.R.B. Análise de decisão investimentos e financiamentos: Engenharia Econômica - teoria e prática. 4.ed. São Paulo: Atlas, 1995. 216p.

KAMPF, A.N. A floricultura brasileira em números. Revista Brasileira de Horticultura e Plantas Ornamentais, v.3, n.1, p.1-7, 1997.

KELLY, M.K. Greenhouse coverings: which one to choose ? Flora Culture International, v.5, n.11, p.16-17, Nov. 1995.

LAWS, N. All the world's a rose. Flora Culture International, v.11, n.1, p.26-30, Jan. 2001.

LEMONS, L. Greenhouse of the $21^{\text {st }}$ century. Flora Culture International, v.9, n.4, p.18-20. Apr. 1999.

LOPES, F. Dia das mães agita o mercado das flores. Valor Econômico. Valor Agronegócios, São Paulo, 07 maio 2003. p.B-10.

MARQUES, R.W. da C. Avaliação da sazonalidade de flores e plantas ornamentais no Estado de São Paulo. Piracicaba, 2002. 114p. Dissertação (M.S.) - Escola Superior de Agricultura "Luiz de Queiroz", Universidade de São Paulo.

MATSUNAGA, M.; OKUYAMA, M.H. ; BESSA JUNIOR, A.A. Cultivo em estufa de rosa cortada. Informações Econômicas, v.25, n.8, p.49-58, ago. 1995.

MATSUNAGA, M. A indústria da flor no mundo e o comércio internacional no Brasil. Revista Brasileira de Horticultura Ornamental, v.3, n.2, p.1-4, 1997. 
PLAISIER, $\mathrm{H}$. The benefits of movable screens in rose production. Flora Culture International, v.8, n.4, p.20-24, Apr. 1998.

SALIGNAC, C. Imigrantes impulsionam o comércio. Panorama rural: revista do agronegócio, n.50, p.52-56, abr. 2003.

SENTELHAS, P.C.; SANTOS, A.O. Cultivo protegido: aspectos microclimáticos. Revista Brasileira de Horticultura Ornamental, v.1, n.2, p.108-115, 1995.

SERVICIO DE INFORMACIÓN Y SENSO AGRÁRIO DEL MINISTÉRIO DE AGRICULTURA Y GANADARIA DEL ECUADOR - SICA. Agronegocios http://www.sica.gov.ec/agronegocios/productos\%20para\%20invertir/flores/Sig.htm (11 jul. 2002)

TIERRA VERDE. Rosas. http://www.tierraverde.cl/principal.php?seleccion=opi21_ interes\&dir=informacion/reportajes/interes.htm (10 oct. 2002)

Von DRATHEN, E. El cultivo de rosas de corte en invernaderos. 3.ed. Resenschulen: W. Kordes' Söhne, 1990. 53p.

ZAFALON, M. Temporada de flores trás empregos e renda. Folha de São Paulo. Agrofolha, São Paulo, 09 set. 2003. p.B-10.

WEISMAN, D. Local rose growers roll with the market. http://www.nctimes.com (11 July 2003) 